\title{
Different responses of East Asian summer rainfall to El Niño decays
}

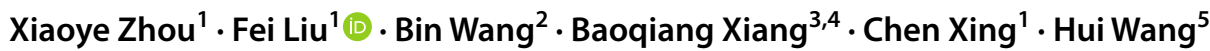

Received: 3 September 2018 / Accepted: 13 February 2019 / Published online: 21 February 2019

(c) The Author(s) 2019

\begin{abstract}
The East Asian summer monsoon (EASM) shows notable change during the summer after El Niño peak. This "delayed" response, however, is variable and difficult to predict. Here, we revisit this issue by separating El Niño decays into early transition and late transition. In the summer after an early transition, the central-to-eastern Pacific evolves into a La Niña condition, with positive rainfall anomaly occurring over most parts of eastern China. In contrast, in the summer after a late transition, the central-to-eastern Pacific sea surface temperature (SST) anomaly remains neutral or slightly above normal; correspondingly, the East Asian rainfall anomaly shows a tripolar structure with positive anomaly over the Yangtze-Huaihe River valley and negative anomalies over northern and southern China. These different rainfall responses are mainly related to different locations of the anomalous anticyclone (AAC) over the western North Pacific (WNP): it is centered at $\left(165^{\circ} \mathrm{E}\right.$, $\left.25^{\circ} \mathrm{N}\right)$ for late-transition El Niños, but at $\left(135^{\circ} \mathrm{E}, 16^{\circ} \mathrm{N}\right)$ for early-transition El Niños. During the late transition, the AACSST feedback, identified by the dipole SST mode consisting of WNP cooling and northern Indian Ocean (NIO) warming, mainly works to support the WNP AAC. During the early transition, the AAC-SST feedback is weak and mainly attributed to NIO warming. The strong easterly anomaly over the western equatorial Pacific, which is tied to the central-to-eastern equatorial Pacific cooling and dipole precipitation pattern from western equatorial Pacific to the Maritime Continent, occurs to support the $\mathrm{AAC}$ and pulls it equatorward. These distinct responses exist in the last century, and the CMIP5 models can reproduce these distinct responses well except that the models underestimate the AAC-SST feedback for late-transition El Niños. The findings in this study help predict the EASM rainfall in post-El Niño years, but the key is the accurate prediction of the timing of decay.
\end{abstract}

Keywords East Asian summer monsoon · Early-transition El Niño · Anomalous anticyclone · AAC-SST feedback · Equatorial easterly feedback $\cdot$ Dipole precipitation pattern

\section{Introduction}

The East Asian summer monsoon (EASM), often called the Meiyu, Changma, or Baiu, features a single most important southwest-northeast tilted rain band over East Asia (Ding

Fei Liu

liuf@nuist.edu.cn

1 Earth System Modeling Center and Climate Dynamics Research Center, Nanjing University of Information Science and Technology, Nanjing 210044, China

2 Department of Atmospheric Sciences and Atmosphere-Ocean Research Center, University of Hawaii at Manoa, Honolulu, HI 96822, USA

3 NOAA/Geophysical Fluid Dynamics Laboratory, Princeton, NJ, USA

4 University Corporation for Atmospheric Research, Boulder, CO, USA

5 School of Atmospheric Sciences, Sun Yat-sen University, Guangzhou 510000, China and Chan 2005). The system affects the East Asian countries including China, Japan, Korea, and Mongolia (Kubota et al. 2016), home to around one-fifth of the population in the world.

As an active climate system, the EASM in the boreal summer has a strong response to the El Niño peak in the boreal winter two seasons earlier, and the EASM is much enhanced, accompanied by the intensified Pacific-Japan pattern (Huang and Sun 1992; Nitta 1986). The convection over the western North Pacific (WNP) is much suppressed, while the northeastward-slanted rain band over East Asia is greatly enhanced (Wang et al. 2003). The interannual variation of 
EASM induced by the El Niño-South Oscillation (ENSO) can lead to severe flood or drought in the East Asian region, harming grain production, ecological environment, and the gross domestic product (Chang et al. 2000; Gadgil and Gadgil 2006; Li 2014).

The recurrent anomalous large-scale anticyclone (AAC) after an El Niño event was found to be the key for our understanding of why the El Niño peak in the boreal winter can affect the EASM two seasons later (Chang et al. 2000; Wang et al. 2000). There are mainly two mechanisms for explaining the development and maintenance of the WNP AAC. The first mechanism is the monsoon-ocean interaction through a positive thermodynamic feedback. This mechanism was first proposed by Wang et al. (2000), which attributed persistence of the WNP AAC primarily to a positive thermodynamic feedback between the AAC and underlying sea surface cooling in the WNP. To the southeast of the AAC, sea surface temperature (SST) is cool because the anomalous northeasterly winds strengthen mean easterlies, thereby enhancing evaporation/entrainment. Conversely, the resultant ocean cooling would, in turn, reduce in situ precipitation heating, hence generating descending Rossby waves that reinforce the AAC in their westward decaying journey. The other mechanism focuses on the effect of the Indian Ocean as a capacitor (Xie et al. 2009), namely, the tropical Indian Ocean basin-wide warming, caused by the wind-induced surface heat exchange (WISHE) and oceanic dynamics associated with El Niño evolution (Du et al. 2009; Ohba and Ueda 2005, 2009), acts like a capacitor, which causes tropospheric temperature to increase, emanating a baroclinic Kelvin wave into the Pacific that induces divergence in the subtropics and enhances the AAC. This second mechanism has been tested by many Atmospheric General circulation model (AGCM) experiments (Kosaka et al. 2013; Ohba and Ueda 2006; Wu et al. 2009; Xie et al. 2009).

It has been firmly established, however, that AGCMs, when forced by observed SST, are unable to simulate properly Asian-Pacific summer monsoon rainfall, and the conventional notion of taking SST as a forcing in a heavily precipitating monsoon region is a fundamental flaw that leads to errors in simulations and seasonal forecasts (Wang et al. 2004, 2005). Using coupled General circulation model (GCM) experiments, Wang et al. (2013) showed that an initial cooling in the WNP can induce and maintain the AAC. This westward extension of the AAC to the northern Indian Ocean (NIO) can induce warming there by suppressing convection/cloudiness and reducing surface latent heat flux (also see Du et al. 2009). Conversely, the NIO warming can help sustain the AAC. Detailed explanation of the NIO warming effect can be found in Xiang et al. (2013). Therefore, it is the positive feedback between the Indo-Pacific AAC and underlying dipolar SST anomalies that plays a central role in maintaining the AAC (Wang et al. 2013), although
Stuecker et al. (2015) suggested that the air-sea coupling is a secondary factor, and that the AAC was viewed as a combination mode of the quasi-symmetric linear ENSO response and the meridionally antisymmetric annual-cycle-modulated ENSO response. Recently, the coupled mode concept has been confirmed by Xie et al. (2016); the authors redefined the Indian Ocean capacitor as "a coupled ocean-atmosphere mode that builds on two mechanisms, i.e., the SST cooling in the WNP and the SST warming in the NIO, in a two-stage evolution". In this study, we refer to this first mechanism as the positive feedback between the AAC and SST or the coupled AAC-SST mode.

The second mechanism responsible for the WNP AAC during summer is the forcing from the central-to-eastern Pacific cooling (warming). The AGCM experiments have demonstrated that a central equatorial Pacific cooling can shift the Walker cell, thus reducing convection around $160^{\circ} \mathrm{E}$ and increasing convection over the Maritime Continent (Wang et al. 2013; Xiang et al. 2013). The suppressed convection can directly strengthen the AAC by emanating descending Rossby waves. Meanwhile, the reinforced Maritime Continent convection can enhance the AAC via inducing equatorial easterlies over the western Pacific, generating off-equatorial anticyclonic shear vorticity over the Philippine Sea (Wang et al. 2013). We refer to this second mechanism as the equatorial easterly feedback over the western equatorial Pacific.

These findings were largely based on the composite of all El Niño events. The El Niño decay, however, may be quick or slow (Kug et al. 2006; Mcgregor et al. 2013; Ohba and Ueda 2009; Stuecker et al. 2013; Wu and Song 2017). As a vital characteristic of El Niño, the various lengths of El Niño decaying phase may also be affected by the strength of Indian Ocean SSTs in the El Niño peak phase (Boo et al. 2004; Chen et al. 2012) or by inter-basin coupling between Indian Ocean warming and WNP cooling (Yun et al. 2014). The EASM responses to these different speeds of El Niño transition may differ. For example, the eastern-Pacific El Niño was found to decay much more slowly than the central-Pacific El Niño (Feng et al. 2011; Huang et al. 2009; Yuan and Yang 2012). After the slow-transition eastern-Pacific El Niño, there is an anomalous positive-negative-positive rainfall pattern from East Asia through the western Pacific to the eastern equatorial Pacific, which lasts until the decaying summer. After the fast-transition central-Pacific El Niño, however, there is an anomalous negative-positive-negative rainfall pattern over East Asia and the equatorial Pacific during the entire lifetime of El Niño. Compared to strong El Niños, most moderate El Niños tend to decay more quickly (Lee et al. 2014). In the summer after a moderate El Niño, positive rainfall anomaly appears along the Yellow River-Huaihe valleys and negative rainfall anomaly occurs in the Yangtze River valley and southern China, while an intermediate rainfall pattern with positive rainfall appears over the Yangtze River valley for a 
strong El Niño (Xue and Liu 2008). Wang et al. (2017) also pointed out that strong and moderate El Niño decays may affect the EASM through different mechanisms. Only strong El Niño events can stimulate intense coupled AAC-dipole SST mode, influencing the EASM. A weak El Niño may also enhance the post-El Niño summer rainfall over eastern Asia, but it is through the reemergence of an AAC forced by the rapid cooling in the eastern Pacific.

Due to different speeds of El Niño transition, the impact of El Niño on the EASM varies over the past decades. During the positive Pacific decadal oscillation (PDO) phase, the EASM response in a post-El Niño summer shows a tripolar pattern with positive rainfall anomaly in central China and negative anomalies in the southern and northern parts of China since the El Niño decaying is slow. During the negative PDO phase, the response shows a dipole pattern with positive rainfall anomaly moving northward from southern China in June to northern China in August because the El Niño decaying is fast (Feng et al. 2014).

Although these studies were on different types of El Niño transition, they mainly focused on the El Niño onset location (Feng et al. 2011), El Niño strength (Lee et al. 2014; Wang et al. 2017), and decadal modulation (Feng et al. 2014). Linking EASM response to the El Niño decay rate (fast or slow) may not be adequate. As we will show, what matters to the EASM rainfall is whether the El Niño decays to a neutral state or to a La Niña state by the ensuing summer. For instance, the 1982/83 El Niño decayed fast (the decay rate was large), but the central-to-eastern equatorial Pacific SST remained above average by the summer. It is more proper to call it late decay or late transition to an opposite phase, rather than call it fast decay.

The goals of this study are to investigate different responses of EASM rainfall to early and late transitions from El Niño to La Niña, and to explore the underlying mechanisms associated with the change of the WNP AAC during these two types of El Niño transition. The paper is organized as follows. In Sect. 2, we describe the datasets, models, and analysis methods used. In Sect. 3, we analyze different responses of China summer rainfall after early- and latetransition El Niños. In Sect. 4, we present the underlying mechanisms to explain different WNP AAC changes after these two types of El Niño transition, and propose two indices to represent these mechanisms. In Sect. 5, we test our finding by using long-term datasets and model simulations. Discussion and conclusions are presented in Sect. 6.

\section{Data, models, and methods}

The data used in this study include monthly SST from the National Oceanic and Atmospheric Administration (NOAA) Extended Reconstructed SST version 4 from 1854 to 2016
(ERSST4; Huang et al. 2016), rainfall from the Center for Climate Prediction Merged Analysis of Precipitation from 1979 to 2016 (CMAP; Xie and Arkin 1997), and rainfall measurements at 160 stations from the Chinese Meteorological Data Center from 1951 to 2016. The monthly precipitation data from the Global Precipitation Climatology Project version 2.3 (GPCP, v2.3; Adler 2003) are also used, and similar results as those from the CMAP are obtained. Monthly wind and sea-level pressure (SLP) data are obtained from the National Centers for Environmental Prediction-National Center for Atmospheric Research (NCEP-NCAR) reanalysis II (Kalnay et al. 1996). These data all cover the short period of 1979-2016.

To test the results obtained from these observations, we use long-term datasets and simulations. The long-term datasets include the global land precipitation from the latest version of the Climatic Research Unit (CRU, TS4.01) for 1901-2016 (Harris et al. 2014) and monthly 850-hPa wind from the twentieth century reanalysis for 1901-2014 (Compo et al. 2011). We also use the historical run outputs during 1901-2004 from 38 coupled general circulation models (CGCMs) in phase 5 of the Coupled Model Intercomparison Project (CMIP5) (Taylor et al. 2012). Details including model names, institutions, and resolutions are listed in Table 1.

The Niño3.4 index, defined by the box $\left(120^{\circ}-170^{\circ} \mathrm{W}\right.$, $5^{\circ} \mathrm{S}-5^{\circ} \mathrm{N}$ ) averaged SST anomalies, is used to identify El Niño events in both observations and simulations. The climatological mean and annual cycle for the study period are removed to obtain anomalies. An El Niño event is defined by the winter (DJF) mean Niño3.4 index above 0.5 standard deviation (Fig. 1). Following this criterion, 10 El Niño events for the period of 1979-2016 are selected: 1982/1983, 1987/1988, 1991/1992, 1994/1995, 1997/1998, 2002/2003, 2004/2005, 2006/2007, 2009/2010, and 2015/2016.

To separate the early- and late-transition events, the summer (JJA) Niño3.4 index is used as a reference. An early-transition El Niño is defined by the summer-averaged Niño3.4 index in the ensuing year (after the peak phase) being below zero, and a late-transition event is defined by the summer-averaged Niño3.4 index in the ensuing year being above zero. Thus, we have six early-transition events (1987/1988, 1994/1995, 1997/1998, 2006/2007, 2009/2010, and 2015/2016) and four late-transition events (1982/1983, $1991 / 1992,2002 / 2003$, and 2004/2005) for the period of 1979-2016. Different from conventional definitions, early or late transition here mainly reflects the ensuing summer SST condition over the central-to-eastern equatorial Pacific rather than the decaying tendency of El Niño, and the classification is somewhat different from that used in previous studies (e.g., Feng et al. 2011, 2014; Wang et al. 2017).

Using the same criterion on ERSST4 for the period of 1901-2016, we have 15 early-transition events (1902/1903, 
Table 1 A list of 38 CMIP5 climate models used in this study

\begin{tabular}{|c|c|c|}
\hline Model name & Institution & $\begin{array}{l}\text { Resolution (latitude } \\
\text { grid } \times \text { longitude grid) }\end{array}$ \\
\hline ACCESS1-0 $0^{(\mathrm{E})}$ & $\begin{array}{l}\text { Commonwealth Scientific and Industrial Research Organization/Bureau of Meteorology, } \\
\text { CSIRO-BOM }\end{array}$ & $145 \times 192$ \\
\hline bcc-csm1-1 $1^{(\mathrm{E})}$ & Beijing Climate Center, BCC & $64 \times 128$ \\
\hline bcc-csm1-1-m ${ }^{(\mathrm{E})}$ & $\mathrm{BCC}$ & $160 \times 320$ \\
\hline $\mathrm{CCSM} 4^{(\mathrm{E})}$ & National Center for Atmospheric Research, NCAR & $192 \times 288$ \\
\hline CESM1-BGC ${ }^{(\mathrm{E})}$ & NCAR & $192 \times 288$ \\
\hline CESM1-FASTCHEM ${ }^{(\mathrm{E})}$ & NCAR & $192 \times 288$ \\
\hline CESM1-WACCM ${ }^{(\mathrm{E})}$ & NCAR & $96 \times 144$ \\
\hline $\mathrm{CMCC}_{-\mathrm{CMS}}{ }^{(\mathrm{E})}$ & Centro Euro-Mediterraneo sui Cambiamenti Climatici, CMCC & $96 \times 192$ \\
\hline $\mathrm{CNRM}^{-\mathrm{CM} 5} 5^{(\mathrm{E})}$ & $\begin{array}{l}\text { Centre National de Recherches Météorologiques, Centre Européen de Recherche et de Forma- } \\
\text { tion Avancée en Calcul Scientifique, CNRM-CERFACS }\end{array}$ & $128 \times 256$ \\
\hline CNRM-CM5-2 $2^{(\mathrm{E})}$ & CNRM-CERFACS & $128 \times 256$ \\
\hline GFDL-CM3 $3^{(\mathrm{E})}$ & Geophysical Fluid Dynamics Laboratory, NOAA-GFDL & $90 \times 144$ \\
\hline GFDL-ESM2G $^{(\mathrm{E})}$ & NOAA-GFDL & $90 \times 144$ \\
\hline GFDL-ESM2M ${ }^{(\mathrm{E})}$ & NOAA-GFDL & $90 \times 144$ \\
\hline GISS-E2-H-CC ${ }^{(\mathrm{E})}$ & NASA/GISS (Goddard Institute for Space Studies), NASA-GISS & $90 \times 144$ \\
\hline GISS-E2-R ${ }^{(E)}$ & NASA-GISS & $90 \times 144$ \\
\hline GISS-E2-R-CC ${ }^{(\mathrm{E})}$ & NASA-GISS & $90 \times 144$ \\
\hline HadGEM2-AO ${ }^{(\mathrm{E})}$ & $\begin{array}{l}\text { National Institute of Meteorological Research, Korea Meteorological Administration, NIMR- } \\
\text { KMA }\end{array}$ & $145 \times 192$ \\
\hline HadGEM2-CC ${ }^{(\mathrm{E})}$ & Met Office Hadley Centre, MOHC & $145 \times 192$ \\
\hline IPSL-CM5A-LR ${ }^{(\mathrm{E})}$ & Institut Pierre Simon Laplace, IPSL & $96 \times 96$ \\
\hline IPSL-CM5A-MR ${ }^{(\mathrm{E})}$ & IPSL & $143 \times 144$ \\
\hline IPSL-CM5B-LR ${ }^{(\mathrm{E})}$ & IPSL & $96 \times 96$ \\
\hline $\operatorname{MIROC}^{(\mathrm{E})}$ & $\begin{array}{l}\text { Atmosphere and Ocean Research Institute (The University of Tokyo), National Institute } \\
\text { for Environmental Studies, and Japan Agency for Marine-Earth Science and Technology, } \\
\text { MIROC }\end{array}$ & $128 \times 256$ \\
\hline MRI-CGCM3 $3^{(\mathrm{E})}$ & Meteorological Research Institute, MRI & $160 \times 320$ \\
\hline MRI-ESM1 ${ }^{(\mathrm{E})}$ & MRI & $160 \times 320$ \\
\hline NorESM1-M ${ }^{(E)}$ & Bjerknes Centre for Climate Research, Norwegian Meteorological Institute, NCC & $96 \times 144$ \\
\hline NorESM1-ME ${ }^{(\mathrm{E})}$ & 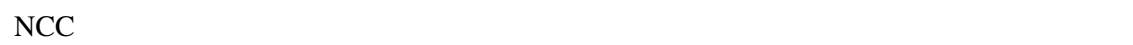 & $96 \times 144$ \\
\hline ACCESS1-3 $3^{(\mathrm{L})}$ & CSIRO-BOM & $145 \times 192$ \\
\hline CanESM2 $2^{(\mathrm{L})}$ & Canadian Centre for Climate Modelling and Analysis, CCCMA & $64 \times 128$ \\
\hline CMCC-CESM $^{(\mathrm{L})}$ & $\mathrm{CMCC}$ & $48 \times 96$ \\
\hline $\mathrm{CMCC}^{-\mathrm{CM}^{(\mathrm{L})}}$ & CMCC & $240 \times 480$ \\
\hline CSIRO-Mk3-6-0 ${ }^{(\mathrm{L})}$ & $\begin{array}{l}\text { Commonwealth Scientific and Industrial Research Organization/Queensland Climate Change } \\
\text { Centre of Excellence, CSIRO-QCCCE }\end{array}$ & $96 \times 192$ \\
\hline HadGEM2-ES ${ }^{(\mathrm{L})}$ & $\mathrm{MOHC}$ & $145 \times 192$ \\
\hline inmem $4^{(\mathrm{L})}$ & Russian Academy of Sciences, Institute of Numerical Mathematics, INM & $120 \times 180$ \\
\hline MIROC-ESM ${ }^{(\mathrm{L})}$ & MIROC & $64 \times 128$ \\
\hline MIROC-ESM-CHEM ${ }^{(\mathrm{L})}$ & MIROC & $64 \times 128$ \\
\hline MPI-ESM-LR ${ }^{(\mathrm{L})}$ & Max Planck Institute for Meteorology, MPI-M & $96 \times 192$ \\
\hline MPI-ESM-MR ${ }^{(\mathrm{L})}$ & MPI-M & $96 \times 192$ \\
\hline MPI-ESM-P ${ }^{(L)}$ & MPI-M & $96 \times 192$ \\
\hline
\end{tabular}

Superscripts "E" and "L" denote early- and late-transition models, respectively

1905/1906, 1911/1912, 1923/1924, 1941/1942, 1958/1959, 1963/1964, 1969/1970, 1972/1973, 1977/1978, 1987/1988, 1997/1998, 2006/2007, 2009/2010, and 2015/2016) and 10 late-transition events $(1914 / 1915,1919 / 1920,1925 / 1926$, 1930/1931, 1965/1966, 1979/1980, 1982/1983, 1991/1992, $2002 / 2003$, and 2004/2005). The 2015/2016 El Niño is not 
Fig. 1 Classification of earlyand late-transition El Niños. Shown are seasonal evolutions of Niño3.4 index (dashed curves; ${ }^{\circ} \mathrm{C}$ ) for a six early-transition and $\mathbf{b}$ four late-transition El Niños during the period of 1979-2016. Thick black curve denotes the composite of all ten selected El Niños. Blue curve in a denotes the composite of six early-transition El Niños; and red curve in $\mathbf{b}$, the four latetransition El Niños. Error bars indicate the standard deviation spread. Superscripts 0 and 1 of the $\mathrm{x}$-axis denote developing and decaying years of El Niño, respectively. Two grey shadings indicate the preceding winter $\left(\mathrm{DJF}^{0}\right)$ and following summer $\left(\mathrm{JJA}^{1}\right)$, respectively
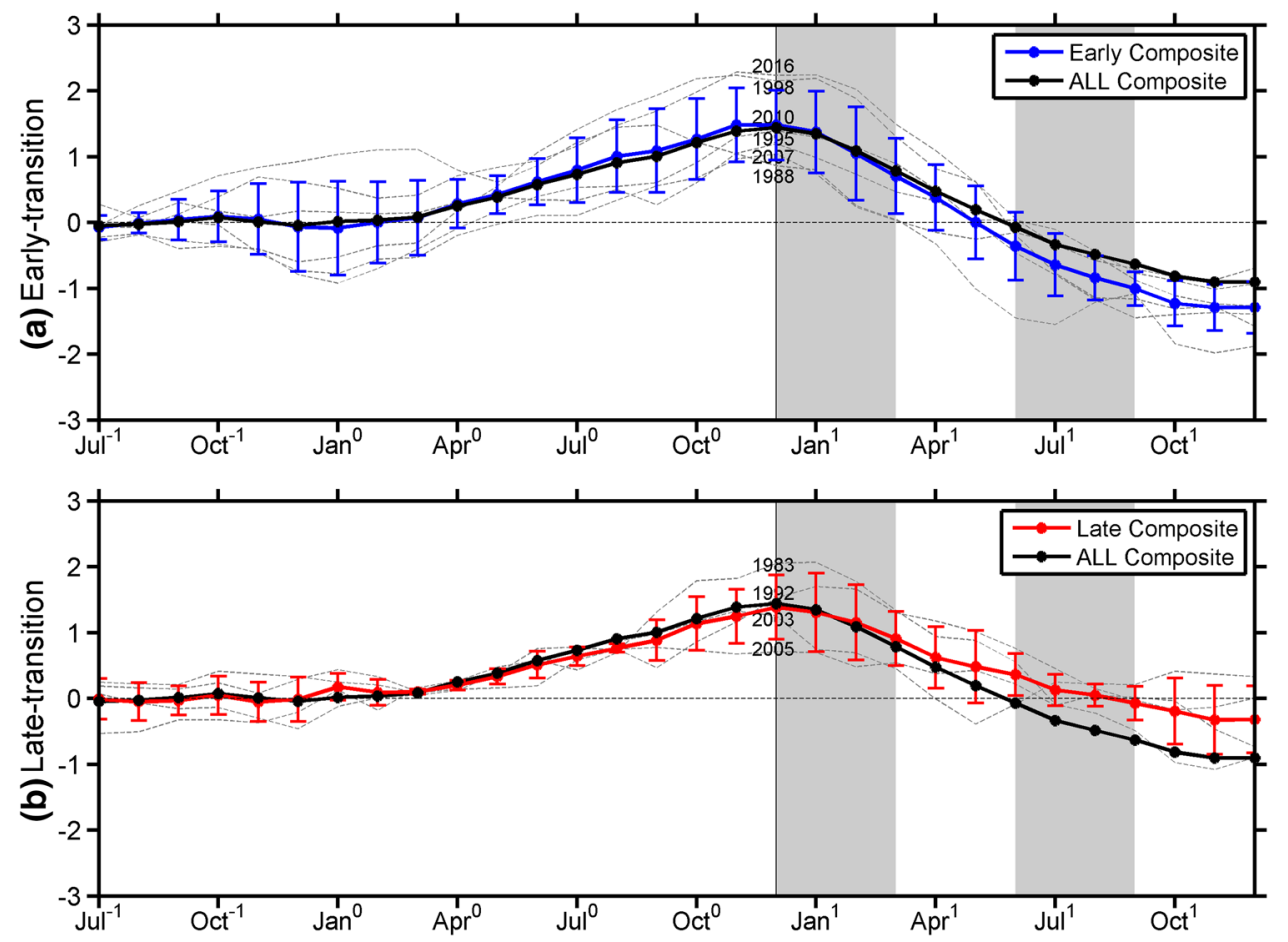

included when calculating the wind anomaly since the Twentieth Century Reanalysis is only available until 2014. Among the 38 models, there are a total of 833 El Niño events during 1901-2004, and they are separated into 437 early- and 396 late-transition El Niños.

To avoid the center location of El Niño controlling the classification results, the Niño3 index is also used to distinguish the early- and late-transition El Niños. The year of 1997/1998 is classified as a late-transition El Niño when the Niño3 index is used. However, the composite results are similar regardless which Niño index is used. In the rest of this paper, we report results using the Niño3.4 index.

After each early-transition event, cold SST anomaly already appears in the following summer, denoted by negative Niño3.4 index (Fig. 1a), which means that these La Niña-like anomalies in the summer may have direct effects on the EASM. After each late-transition El Niño, neutral anomaly in the Niño3.4 index is found in the boreal summer (Fig. 1b). To identify EASM responses to these early- and late-transition El Niños, composite analysis is performed in this study, and significance is tested via Student's $t$-test.

\section{EASM responses to different El Niño transitions}

\subsection{Rainfall response in China}

Figure 2 shows the composite summer rainfall anomaly over China for all ten El Niños, with six early-transition and four late-transition El Niños. According to the composite of all ten selected El Niños, the Chinese summer rainfall anomaly mainly shows a sandwich pattern with positive anomaly over the Yangtze-Huaihe valleys and negative anomalies over southeastern and northeastern China (Fig. 2a), consistent with previous findings (Xue and Liu 2008; Zhang and Sumi 2002; Zhang et al. 2009).

In the summer after the early-transition El Niño, positive precipitation anomaly appears over the entire southeastern China, except for the lower reaches of the Yangtze River and in the coastal regions of southeastern China (Fig. 2b), consistent with Fig. 5e of Feng et al. (2014). After the late-transition El Niño, positive rainfall anomaly mainly occurs over the Yangtze-Huaihe River valleys and negative anomalies appear over northeastern and southern China, resulting in a prominent tripolar pattern (Fig. 2c), consistent with Fig. 5a of Feng et al. (2014) and Fig. 7a of Wang et al. (2017). It seems that the tripolar rainfall structure obtained from the composite for all $10 \mathrm{El} \mathrm{Niños} \mathrm{is} \mathrm{mainly} \mathrm{due} \mathrm{to} \mathrm{late-transition}$ El Niños.

\subsection{Response of WNP AAC}

The WNP AAC is a major driver of EASM variability in the post-El Niño summer (Zhang 1999; Zhou et al. 2005). Figure 3 shows the responses of WNP AAC strength to these two types of El Niño transition. Following Xie et al. (2016), the AAC strength is represented by SLP or precipitation anomalies over the WNP including the South China Sea and the Philippine Sea $\left(135^{\circ}-155^{\circ} \mathrm{E}, 10^{\circ}-20^{\circ} \mathrm{N}\right)$. For 
(a) All

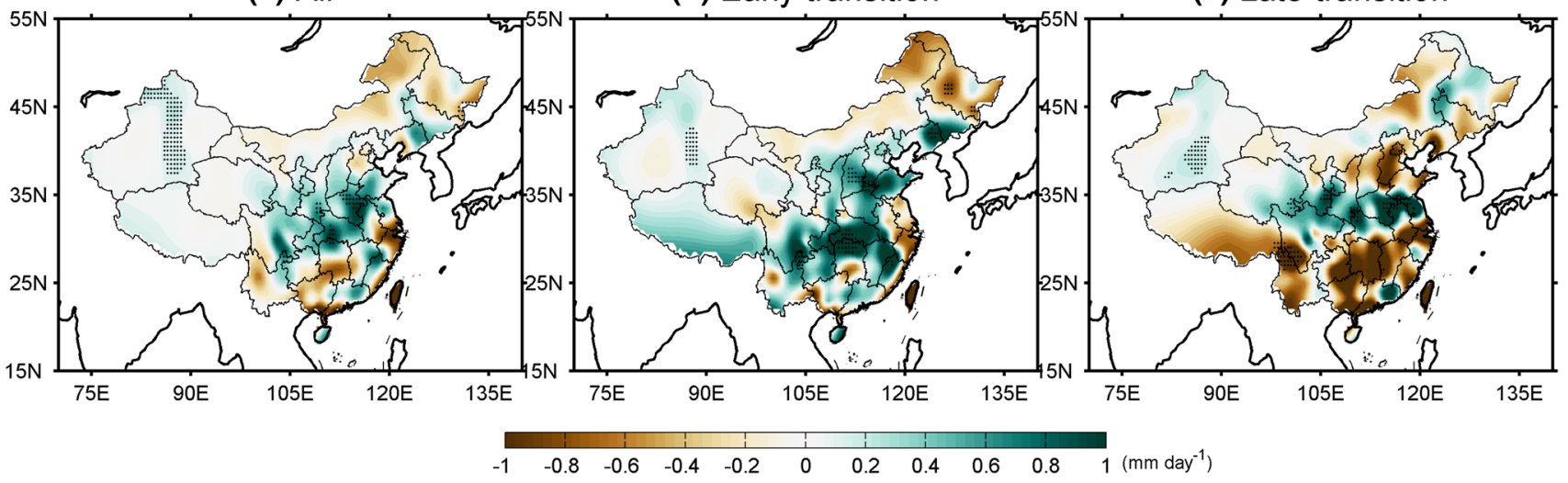

Fig. 2 Post-El Niño summer rainfall anomalies in China. Shown are the composites of summer $\left(\mathrm{JJA}^{1}\right)$ rainfall anomaly (shading; $\mathrm{mm}$ day $^{-1}$ ) in China in a all 10, $\mathbf{b}$ six early-transition, and $\mathbf{c}$ four late-tran- sition El Niños during 1979-2016. Stippling indicates rainfall anomaly significant at the $10 \%$ significance level based on the $t$-test
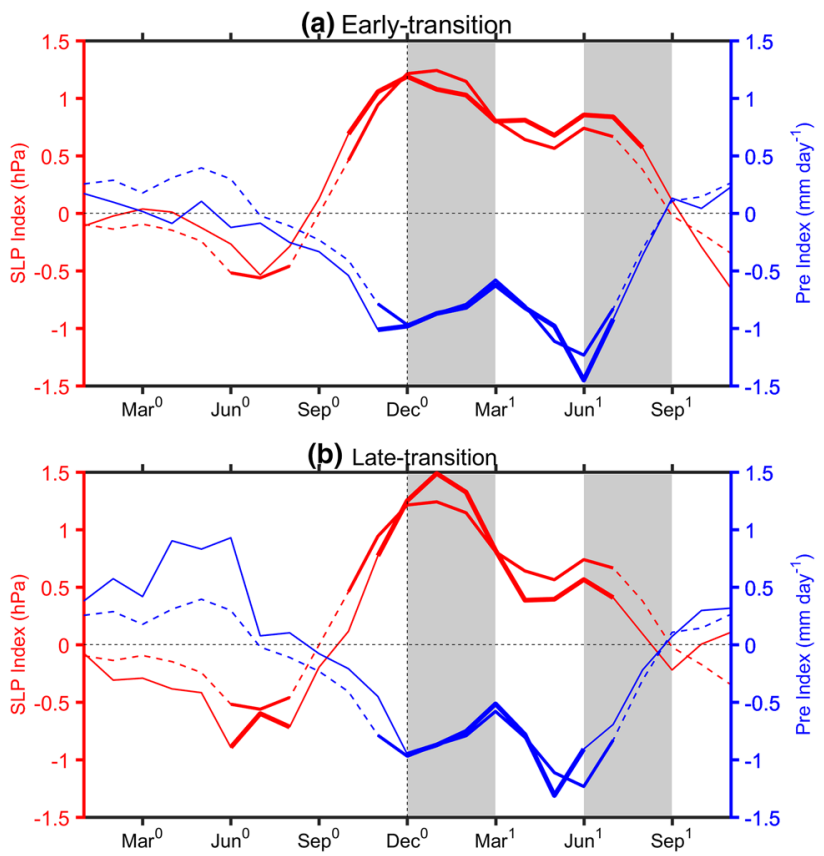

Fig. 3 Evolutions of anomalous anticyclone (AAC) strength for two types of El Niño transition. Shown are the composite seasonal evolutions of sea level pressure (solid red curve; $\mathrm{hPa}$ ) and precipitation (solid blue curve; $\mathrm{mm} \mathrm{day}^{-1}$ ) anomalies averaged over the western North Pacific $\left(135^{\circ}-155^{\circ} \mathrm{E}, 10^{\circ}-20^{\circ} \mathrm{N}\right)$ for a six early-transition and b four late-transition El Niños during 1979-2016. Dashed curves indicate the composite for all $10 \mathrm{El} \mathrm{Niños.} \mathrm{Significant} \mathrm{anomalies}$ at the $10 \%$ significance level based on the $t$-test are indicated using thick lines. Three-month running mean is performed. Superscripts 0 and 1 of the $\mathrm{x}$-axis denote developing and decaying years of El Niño, respectively. Two grey shadings indicate the preceding winter $\left(\mathrm{DJF}^{0}\right)$ and following summer $\left(\mathrm{JJA}^{1}\right)$, respectively

We can conclude that there are distinct differences in the location of AAC for these early- and late-transition El Niños. In the summer after the late-transition El Niño, the 
Fig. 4 Post-El Niño summer AAC locations after two types of El Niño transition. Shown are the composites of sealevel pressure (SLP; shading; $\mathrm{hPa}$ ) anomaly in the summer after $\mathbf{a}$ early-transition and $\mathbf{b}$ late-transition El Niños during 1979-2016. Stippling indicates significant at the $10 \%$ significance level based on the $t$-test (a) Early-transition

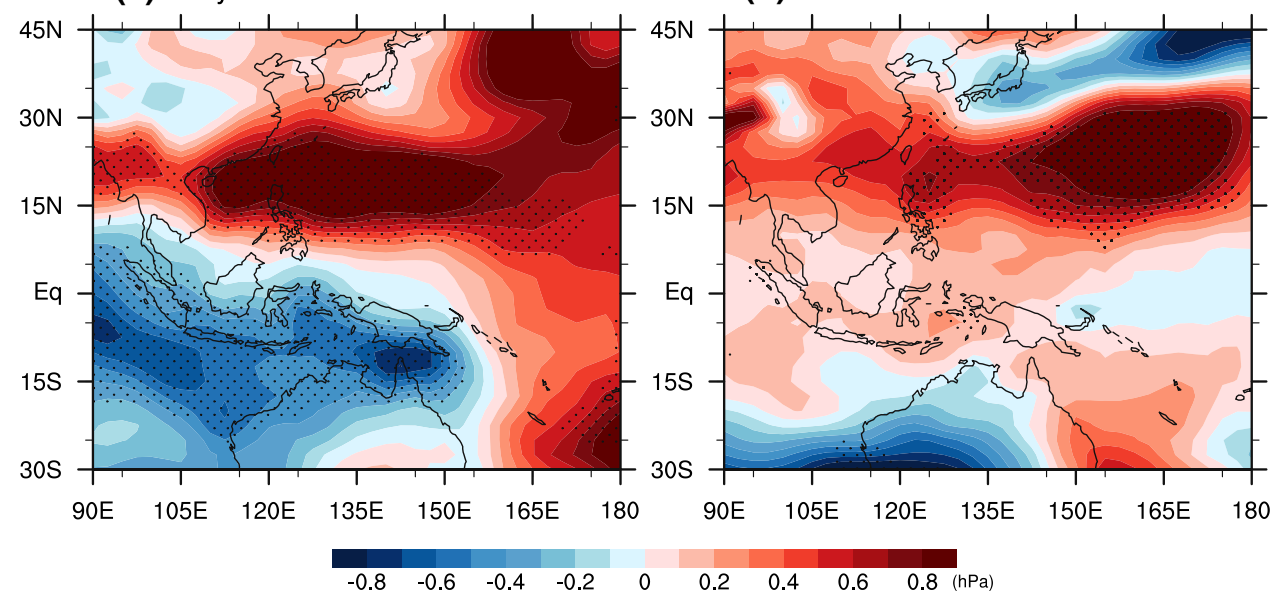

AAC is located near $25^{\circ} \mathrm{N}$ and the westward expansion of the strong high-pressure anomaly suppresses the precipitation over southeastern China via the westward propagation of Rossby gyres (Lin 2008; Liu and Wang 2013). The AAC after the early-transition El Niño moves equatorward with its center near $16^{\circ} \mathrm{N}$, and its strongest high-pressure anomaly also moves out of southeastern China, losing control on the rainfall reduction there. Thus, the different AAC location contributes to different EASM responses after these two types of El Niño transition.

\subsection{Response of Indo-western Pacific}

To address why the AAC location changes in response to the two types of El Niño transition, Fig. 6 shows composite seasonal evolutions of precipitation and $850-\mathrm{hPa}$ wind anomalies over the Indo-western Pacific region. During the boreal winter of early-transition El Niños, significant negative precipitation anomaly appears over the western equatorial Pacific, spanning from East of Australia to the Maritime Continent, while positive anomaly occurs over the western Indian Ocean. The AAC represented by $850-\mathrm{hPa}$ wind anomalies occurs over the Maritime Continent, transporting moisture to southeastern China (Fig. 6a). Although the latetransition El Niño shows similar precipitation anomaly in the boreal winter as the early-transition El Niño, their strengths differ. The late-transition El Niño is linked with stronger drought signals over the Maritime Continent and wet signals over the central-eastern Indian Ocean when compared to the early-transition El Niño (Fig. 6b).

In the following spring of the early-transition El Niño (Fig. 6c), negative precipitation anomaly over the western equatorial Pacific weakens quickly, and weak positive precipitation anomaly appears over the whole Indian Ocean and Maritime Continent, accompanied by a weak anticyclone. After the late-transition El Niño (Fig. 6d), negative

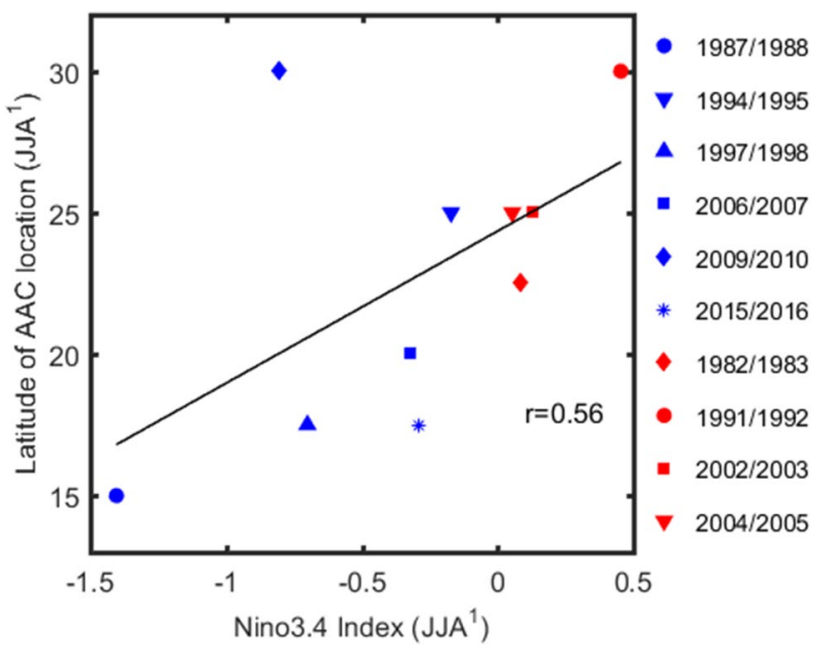

Fig. 5 Relationship between El Niño decaying speed and AAC center. Scatterplots of Niño3.4 index $\left({ }^{\circ} \mathrm{C}\right)$ versus latitude of the AAC center during JJA ${ }^{1}$ for the ten selected El Niños from 1979 to 2016. The blue and red colors denote early- and late-transition El Niños, respectively

precipitation anomaly extends westward from the Maritime Continent to the NIO.

In the following summer, the AAC also shows a different location, with the center at $16^{\circ} \mathrm{N}$ after the early-transition El Niño (Fig. 6e) and at $25^{\circ} \mathrm{N}$ after the late-transition El Niño (Fig. 6f), consistent with the SLP anomaly. Different from the AAC after the late-transition El Niño, the WNP AAC after the early-transition El Niño is dominated by the strong easterly wind anomaly over the equatorial Pacific.

Figure $6 \mathrm{e}, \mathrm{f}$ show positive precipitation anomaly over the entire southeastern China in the summer after the early-transition El Niño and a sandwich pattern after the late-transition El Niño, consistent with the precipitation pattern of China shown in Fig. 2b, c. The Indian Ocean also shows different responses to the two types of El Niño transition. In the 


\section{Early-transition}

(a) $\mathrm{DJF}^{0}$

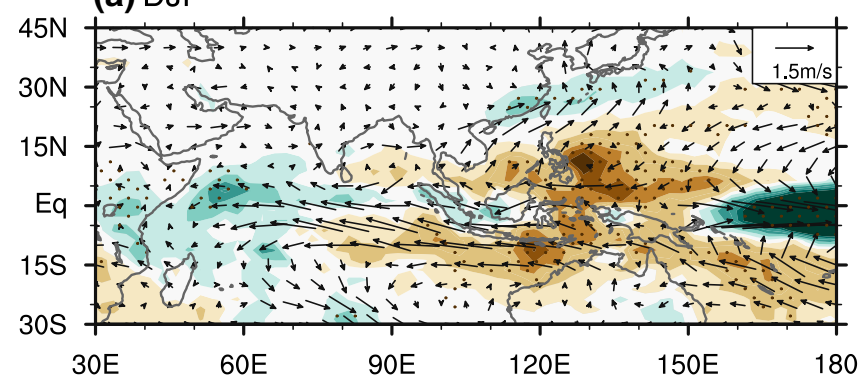

(c) MAM ${ }^{1}$

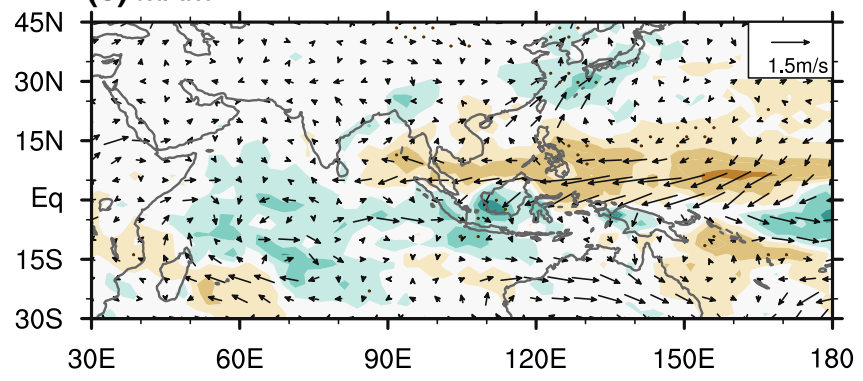

(e) $J J A^{1}$

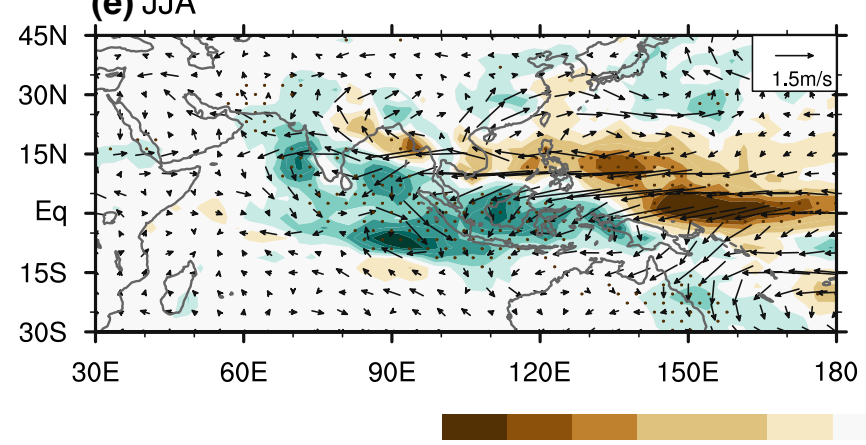

$\begin{array}{lllllllllllll}-3.3 & -2.7 & -2.1 & -1.5 & -0.9 & -0.3 & 0.3 & 0.9 & 1.5 & 2.1 & 2.7 & 3.3 & \left(\mathrm{~mm} \mathrm{day}^{-1}\right)\end{array}$
Late-transition

(b) $\mathrm{DJF}^{0}$

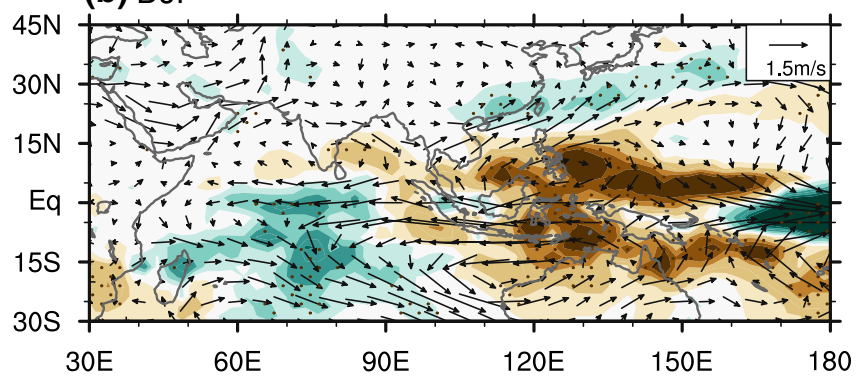

(d) MAM ${ }^{1}$

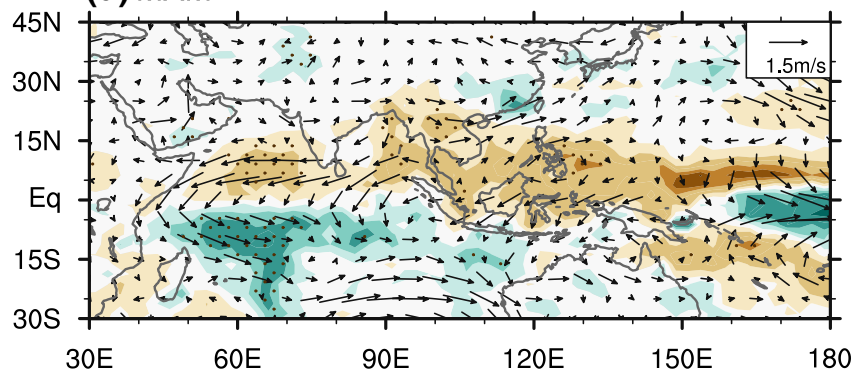

(f) $J J A^{1}$

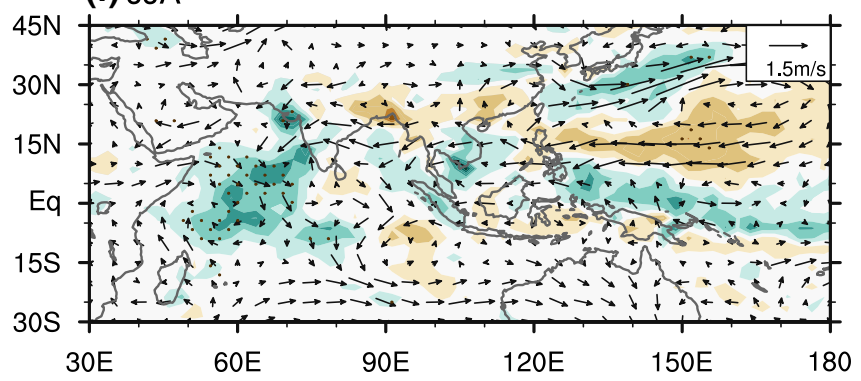

Fig. 6 Evolutions of precipitation and circulation in early- and latetransition El Niños. Composites of precipitation (shading; $\mathrm{mm} \mathrm{day}^{-1}$ ) and $850-\mathrm{hPa}$ wind (vector; $\mathrm{m} \mathrm{s}^{-1}$ ) anomalies in a $\mathrm{DJF}^{0}, \mathbf{c ~ M A M}^{1}$, and $\mathbf{e} \mathrm{JJA}^{1}$ after early-transition El Niños during 1979-2016. b, d, f
Are the same as a, c, e, except for the late-transition El Niños. Superscripts 0 and 1 denote developing and decaying years of the El Niño, respectively. Stippling indicates precipitation anomaly significant at the $10 \%$ significance level based on the $t$-test

over the NIO. The positive precipitation anomaly over the Indian Ocean after the late-transition El Niño, however, is relatively weak, and the easterly wind anomaly only exists over the NIO (Fig. 6f). It seems that the AAC after the latetransition El Niño is related to the rainfall responses over the WNP and NIO, while that the AAC after the early-transition El Niño is related to the strong rainfall response over the Maritime Continent region. 


\section{Two feedbacks related to WNP AAC}

\subsection{Seasonal evolutions of two types of El Niño transition}

Figure 7 shows the composite seasonal evolutions of SST and $850-\mathrm{hPa}$ wind anomalies for the two types of El Niño transition. During the peak phase of the early-transition El Niño, that is, the boreal winter, significant positive SST anomaly appears over the central-to-eastern Pacific, while negative anomaly occurs over the western Pacific. A basinwide warming occurs in the whole Indian Ocean, and the

(a) DJF ${ }^{0}$

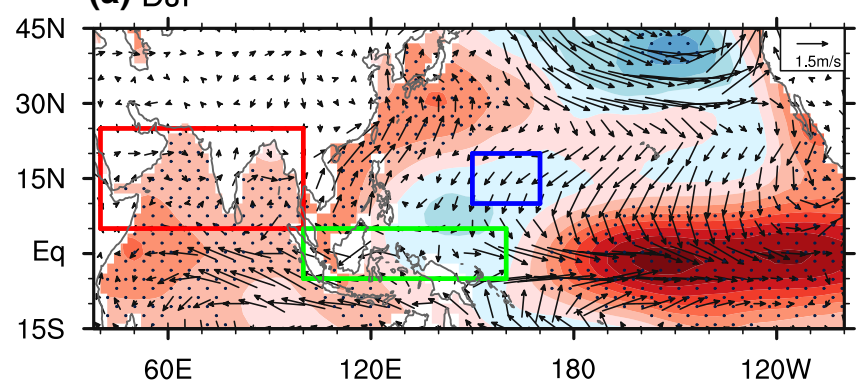

(c) MAM ${ }^{1}$

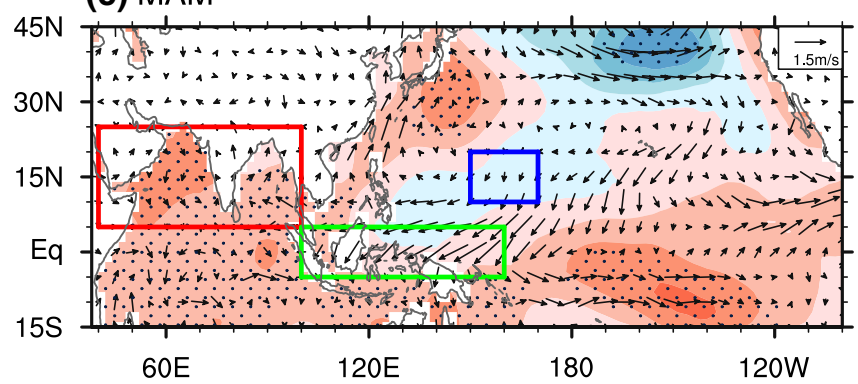

(e) $\mathrm{JJA}^{1}$

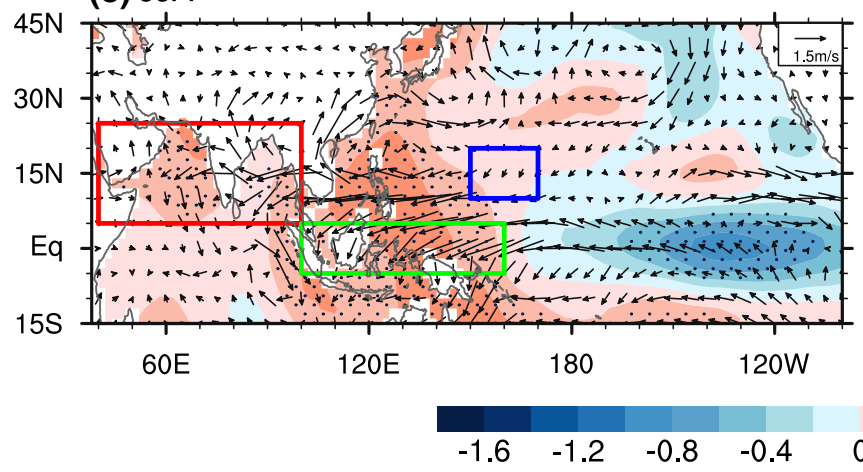

maximum positive SST anomaly appears in the western Indian Ocean. Associated with the SST anomaly, there are westerly wind anomaly over the central equatorial Pacific and easterly wind anomaly over the equatorial Indian Ocean (Fig. 7a). In the following spring (Fig. 7c), positive SST anomaly over the central-to-eastern Pacific decays quickly and becomes weak, accompanied by moderate easterly wind anomaly over the western equatorial Pacific. The Indian Ocean basin-wide warming continues, and the cold SST anomaly in the western Pacific becomes weak.

In the following summer (Fig. 7e), a significant La Niñalike cooling appears in the central-to-eastern Pacific, accompanied by strong easterly wind anomalies from the central

\section{Early-transition}

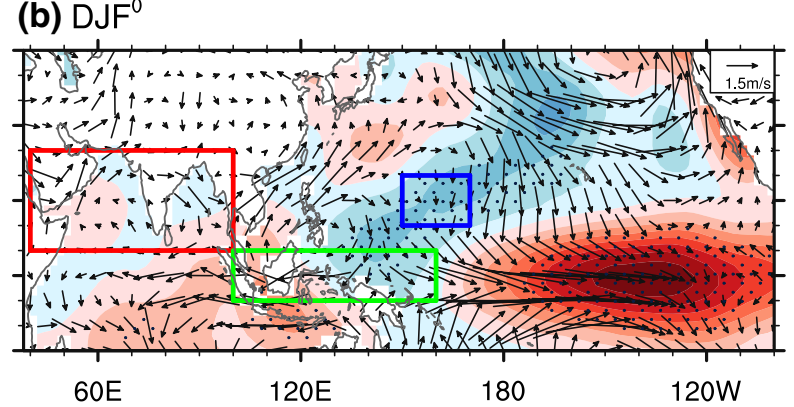

(d) $\mathrm{MAM}^{1}$

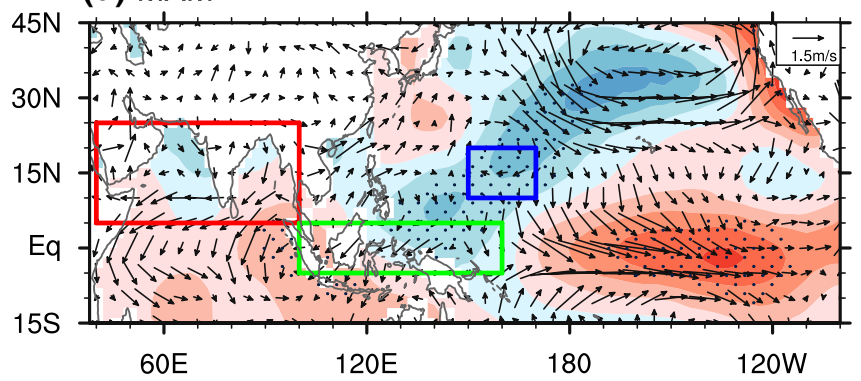

(f) $\mathrm{JJA}^{1}$

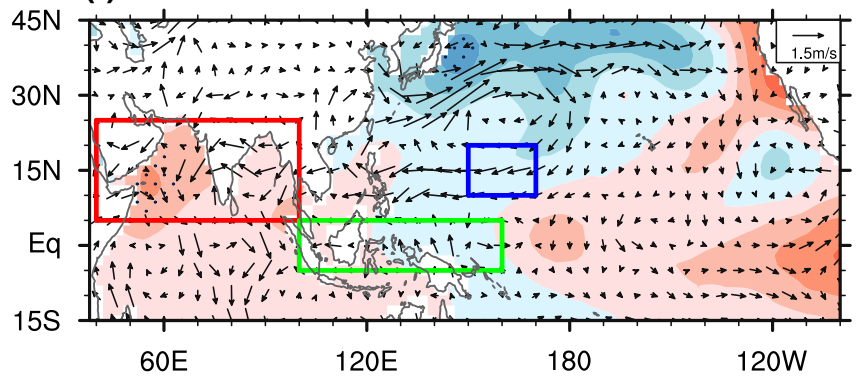

$\begin{array}{llll}0.4 & 0.8 & 1.2 & 1.6\left({ }^{\circ} \mathrm{C}\right)\end{array}$
Fig. 7 Evolutions of early- and late-transition El Niños. Composites of SST (shading; ${ }^{\circ} \mathrm{C}$ ) and $850-\mathrm{hPa}$ wind (vector; $\mathrm{m} \mathrm{s}^{-1}$ ) anomalies in a $\mathrm{DJF}^{0}$, $\mathbf{c} \mathrm{MAM}^{1}$, and e $\mathrm{JJA}^{1}$ after early-transition El Niños during 1979-2016. b, d, f Are the same as a, c, e, except for the late-transition El Niños. Superscripts 0 and 1 denote developing and decaying years of the El Niño, respectively. Red, green, and blue boxes denote the NIO $\left(40^{\circ}-100^{\circ} \mathrm{E}, 5^{\circ}-25^{\circ} \mathrm{N}\right)$, Indo-western equatorial Pacific $\left(100^{\circ}-160^{\circ} \mathrm{E}, 5^{\circ} \mathrm{S}-5^{\circ} \mathrm{N}\right)$, and western North Pacific $\left(150^{\circ}-170^{\circ} \mathrm{E}\right.$, $\left.10^{\circ}-20^{\circ} \mathrm{N}\right)$, respectively. Stippling indicates SST anomaly significant at the $10 \%$ significance level based on the $t$-test 
equatorial Pacific to the Maritime Continent. Significant easterly wind anomaly also appears over the NIO. Consistent with the finding in Kug et al. (2006), this early transition from El Niño to La Niña follows the strong positive phase of Indian Ocean Dipole that peaks in the previous autumn (not shown).

The late-transition El Niño has a different evolution from the early-transition El Niño. In the peak phase (Fig. 7b), significant positive SST anomaly exists in the central-to-eastern equatorial Pacific and central-to-eastern Indian Ocean, while negative SST anomaly appears in the western Pacific and western Indian Ocean. Although the late-transition El Niño is accompanied by similar wind anomaly as the earlytransition El Niño, as shown by the westerly wind anomaly over the central equatorial Pacific and easterly wind anomaly over the equatorial Indian Ocean, the SST gradient over the Indian Ocean is different. The late-transition El Niño has a negative Indian Ocean Dipole-like anomaly in the Indian Ocean, while the early-transition El Niño has a positive Indian Ocean Dipole-like anomaly. The negative SST anomaly in the WNP around $160^{\circ} \mathrm{E}$ for the late-transition El Niño is also much stronger than that for the early-transition El Niño.

In the following spring after the late-transition El Niño, the central Pacific is still dominated by significant positive SST anomaly, and the cold SST anomaly can remain in the WNP, accompanied by northeasterly wind anomaly there (Fig. 7d). The AAC and WNP cold SST anomaly constitute a positive thermodynamic feedback. In summer, warm SST anomaly appears in the NIO, accompanied by easterly wind anomaly there (Fig. 7f). Both positive SST anomaly in the central-to-eastern equatorial Pacific and cold SST anomaly in the WNP decay, but negative SST anomaly still exists over the WNP.

In the summer after the early-transition El Niño, the equatorial easterly anomaly, tied to the central-to-eastern equatorial Pacific cooling, supports the WNP AAC, while only the NIO warming exists for the NIO warming-WNP cooling dipole mode (Fig. 7e). For the late-transition El Niño, the positive SST anomaly in the central equatorial Pacific can last from the peak phase of winter to the following summer, accompanied by strong cold SST anomaly in the WNP (Fig. 7b, d, f). The NIO warming-WNP cooling dipole mode occurs in summer. Besides, the southwestward shift of the westerly jet in the mid-latitude in the late-transition El Niño may facilitate the development of WNP AAC (Fig. 7f), while there are no obvious jets in the ensuing summer for the earlytransition El Niño (Fig. 7e).
From Fig. 7, the early (late) transition from El Niño to La Niña can be attributed to the strong (weak) Indian Ocean basin-wide warming from peak phase to the following spring, consistent with previous findings (Kug et al. 2006; Ohba and Ueda 2007; Ohba and Watanabe 2012). We can also refer to this early transition as the strong Indian Ocean SST warming type transition.

\subsection{Seasonal evolutions of two feedbacks}

Based on the analysis of SST and wind anomalies, we find two key factors for different AAC evolutions after the two types of El Niño transition, that is, the AAC-SST feedback and the equatorial easterly feedback. Figure $8 \mathrm{a}, \mathrm{b}$ show the WNP part of the AAC-SST feedback for the two types of El Niño transition. During the previous autumn of the earlytransition El Niño, negative SST anomaly peaks near $150^{\circ} \mathrm{E}$, accompanied by anomalous westerlies (Fig. 8a). Meanwhile, the easterly wind anomaly prevails from the previous winter to the following spring, perturbed by short-term westerly wind anomaly in the late-winter. The weak cold SST anomaly in the WNP persists from the boreal winter to spring, with the cold SST anomaly center retreating to the east of $160^{\circ} \mathrm{E}$ in the late-winter. The WNP wind-evaporation-SST (WES) feedback is weak and only appears from the latewinter to the early-spring for the early-transition El Niño. For the late-transition El Niño (Fig. 8b), the strong cold SST anomaly in the WNP lasts from the boreal winter to the following summer, which suppresses convective activities and decreases latent heat release. In the ensuing spring, the anomalous northeasterly enhances the cooling on the eastern flank of the AAC, exciting descending westwardpropagating Rossby waves and maintaining the WNP AAC (Wang et al. 2000).

Figure 8c, d show the Indian Ocean part of the AAC-SST feedback. For the early-transition El Niño (Fig. 8c), the whole Indian Ocean warms up prominently from the previous autumn to the ensuing summer, exciting anomalous easterly over the equatorial Indian Ocean until the late-spring. The strongest warming in the NIO appears in the late-winter due to the anomalous westerly that offsets the northeasterly monsoon. In the ensuing summer, the easterly wind anomaly weakens the southwesterly monsoon and keeps the NIO warm via the WES feedback (Du et al. 2009). The NIO warming can excite the AAC through the Kelvin wave-like response (Xie et al. 2009). For the late-transition El Niño (Fig. 8d), weak positive SST anomaly appears in the southern and equatorial Indian Ocean since the previous autumn, 
Fig. 8 Evolution of two feedbacks for early- and latetransition El Niños. Shown are a composites of meridionally $\left(10^{\circ}-20^{\circ} \mathrm{N}\right)$ averaged SST anomalies (shading; ${ }^{\circ} \mathrm{C}$ ) and 850-hPa zonal wind anomalies (contour; $\mathrm{m} \mathrm{s}^{-1}$ ) as a function of longitude and time, namely, the WNP part of the AAC-SST feedback; c composites of zonally $\left(40^{\circ}-100^{\circ} \mathrm{E}\right)$ averaged SST anomalies (shading; ${ }^{\circ} \mathrm{C}$ ) and 850-hPa zonal wind anomalies (contour; $\mathrm{m} \mathrm{s}^{-1}$ ) as a function of time and latitude, namely, the NIO part of the AAC-SST feedback; e composites of meridionally $\left(5^{\circ} \mathrm{S}-5^{\circ} \mathrm{N}\right)$ averaged precipitation anomalies (shading; $\mathrm{mm}$ day $^{-1}$ ) and 850-hPa zonal wind anomalies (contour; $\mathrm{m} \mathrm{s}^{-1}$ ) as a function of longitude and time, namely, equatorial easterly wind feedback for early-transition El Niños during 1979-2016. b, d, f Are the same as a, c, e, except for the late-transition El Niños. Superscripts 0 and 1 of the $\mathrm{x}$-axis or $\mathrm{y}$-axis denote developing and decaying years of the El Niño, respectively. Blue, red, and black colors denote negative, positive, and zero contours, respectively
Early-transition

\section{(a) WNP}

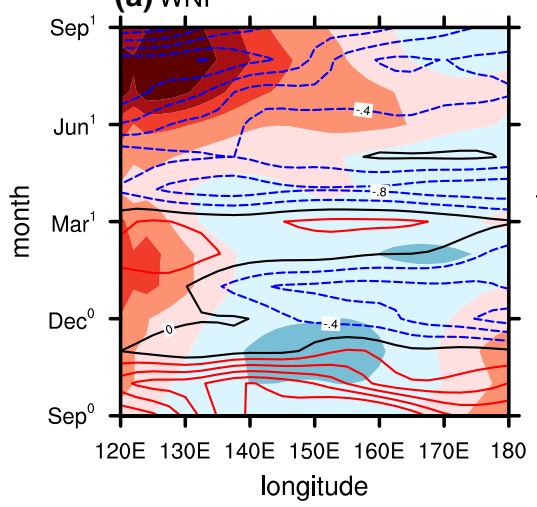

(c) Indian Ocean

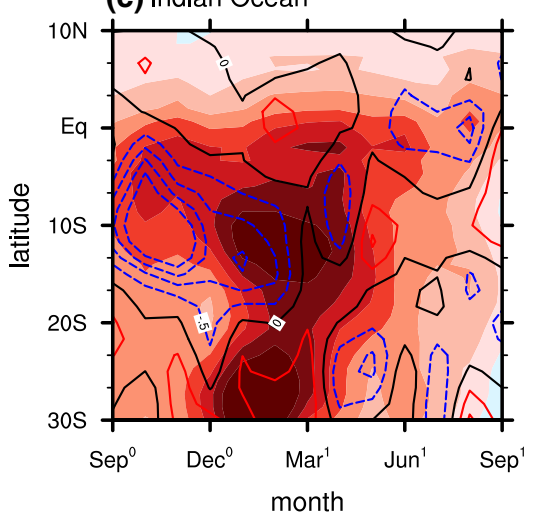

(e) Equatorial Pacific

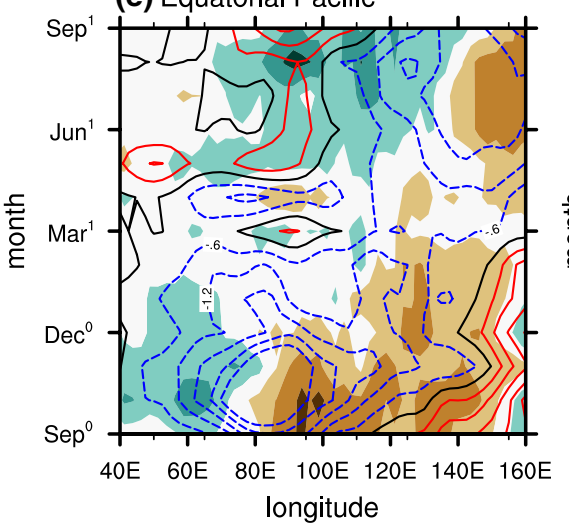

Late-transition

(b) WNP

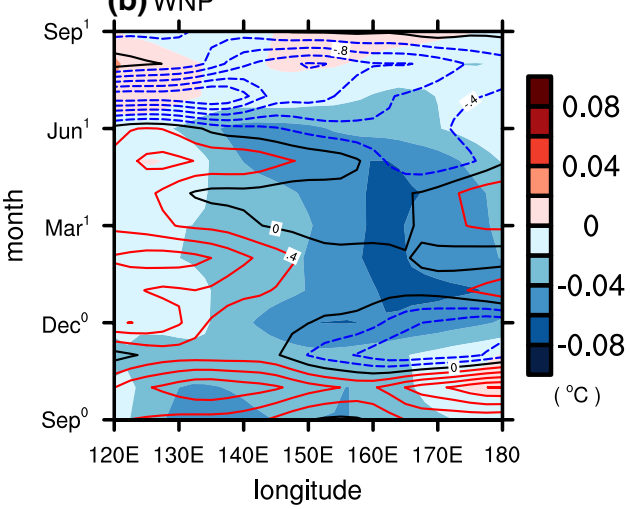

(d) Indian Ocean
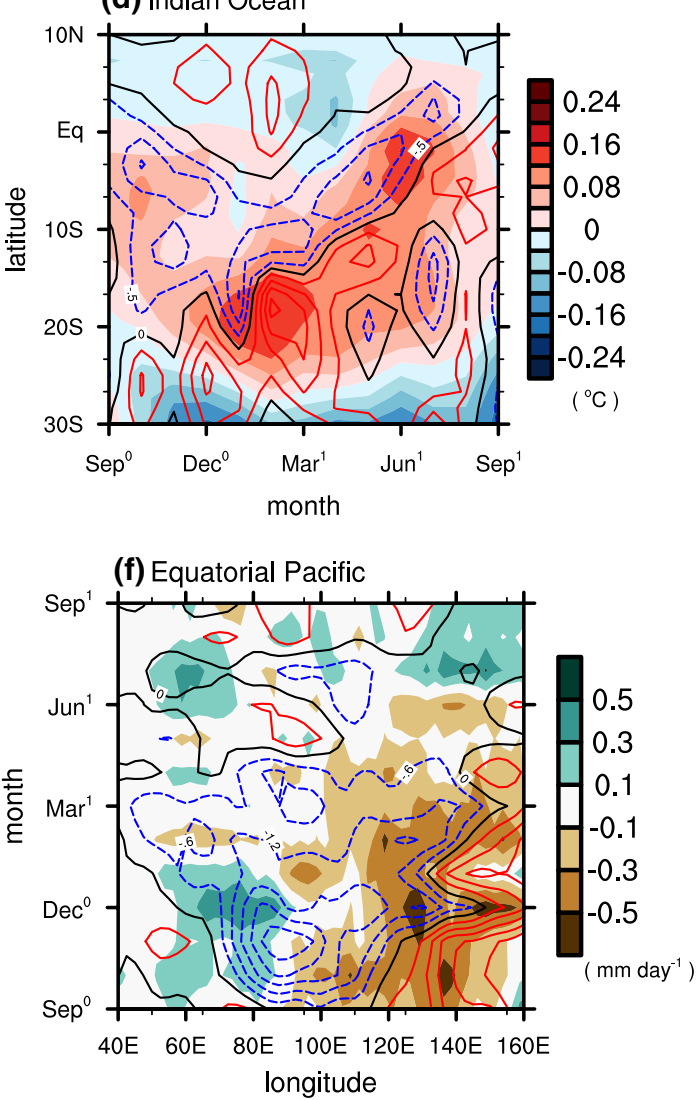

but the significant warm anomaly in the NIO only works since the late-spring, accompanied by anomalous easterly.

Figure 8e, f show the equatorial easterly feedback for these two types of El Niño transition. For the early-transition El Niño (Fig. 8e), the easterly wind anomaly over the equatorial Indo-western Pacific Ocean persists from the previous autumn to the late-spring, perturbed by short-term westerly wind anomaly in March. In the ensuing summer, the strong easterly wind anomaly persists over the western equatorial Pacific, while the westerly wind anomaly appears in the equatorial Indian Ocean, accompanied by strong positive precipitation anomaly. For the late-transition El Niño 
(Fig. 8f), the strong easterly wind anomaly over the equatorial Indo-western Pacific Ocean disappears starting in latespring, and only weak easterly wind anomaly exists over the Maritime Continent in summer. This result indicates that the equatorial easterly feedback only works for the earlytransition El Niño.

\subsection{Indices related to WNP AAC}

For the AAC-SST feedback, the WNP part (Wang et al. 2000) suggests that the zonal SST dipole can sustain the AAC with the cold water on the southeastern flank, strengthening the prevailing northeasterly trade wind. Wang et al. (2013) showed that an initial cooling in the WNP can

(a) SST Index over WNPP
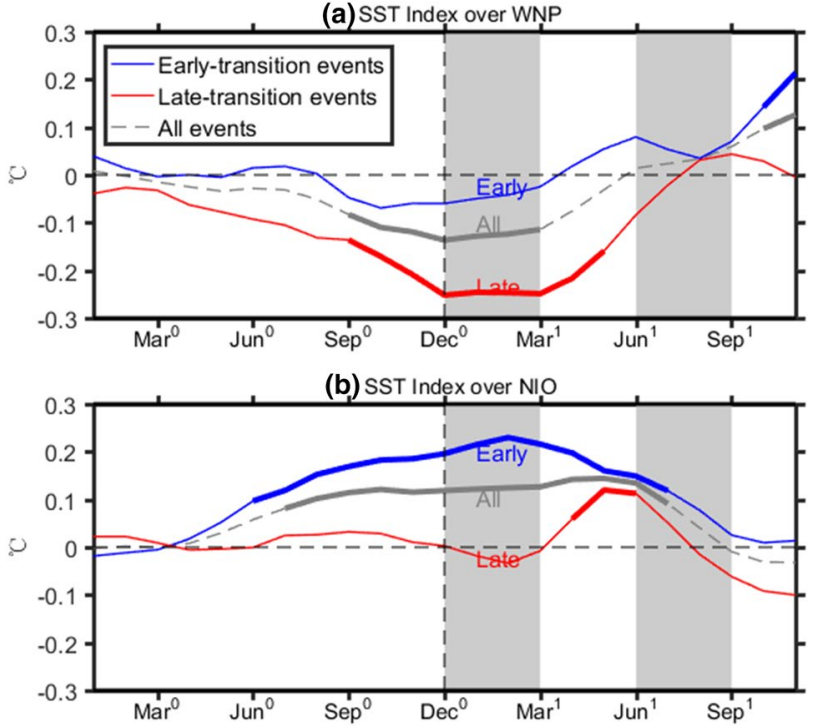

(c) Equatorial Easterly Wind Index

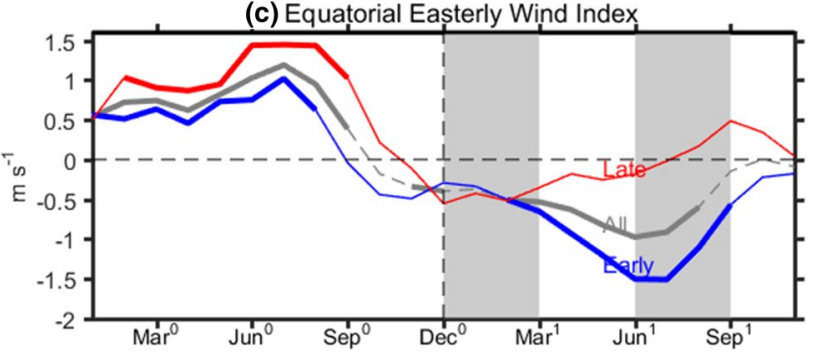

Fig. 9 Seasonal evolutions of two indices for different types of El Niño transition. Shown are a WNP part of the SST index for western North Pacific $\left(150^{\circ}-170^{\circ} \mathrm{E}, 10^{\circ}-20^{\circ} \mathrm{N}\right)$ averaged SST anomalies, b NIO part of the SST index for NIO $\left(40^{\circ}-100^{\circ} \mathrm{E}, 5^{\circ}-25^{\circ} \mathrm{N}\right)$ averaged SST anomalies, and c equatorial easterly wind index for western equatorial Pacific Ocean $\left(100^{\circ}-160^{\circ} \mathrm{E}, 5^{\circ} \mathrm{S}-5^{\circ} \mathrm{N}\right)$ averaged zonal wind anomalies. The blue, red, and grey colors denote the composites of early-transition, late-transition, and all El Niños, respectively. Significant anomalies at the $10 \%$ significance level based on the $t$-test are indicated using thick lines. Superscripts 0 and 1 of the $\mathrm{x}$-axis denote developing and decaying years of the El Niño, respectively. Two grey shadings indicate the preceding winter $\left(\mathrm{DJF}^{0}\right)$ and following summer $\left(\mathrm{JJA}^{1}\right)$, respectively maintain the AAC and induce NIO warming. This part can be defined by the averaged SST anomaly over the WNP $\left(150^{\circ}-170^{\circ} \mathrm{E}, 10^{\circ}-20^{\circ} \mathrm{N}\right)$. Another part, the Indo-Pacific Ocean capacitor feedback (Xie et al. 2009), suggests that the Indian Ocean basin-wide warming can sustain the AAC through the Kelvin wave response, which can be represented by the averaged SST anomaly in the NIO $\left(40^{\circ}-100^{\circ} \mathrm{E}\right.$, $\left.5^{\circ}-25^{\circ} \mathrm{N}\right)$. To represent the equatorward migration of the AAC associated with the early-transition El Niño, the equatorial easterly index, defined by the averaged easterly anomaly over the western equatorial Pacific $\left(100^{\circ}-160^{\circ} \mathrm{E}\right.$, $5^{\circ} \mathrm{S}-5^{\circ} \mathrm{N}$ ) is used.

Figure 9a, b show the SST index for the WNP and NIO parts of the AAC-SST feedback for the two types of El Niño transition. For the late-transition El Niño, the strong negative WNP SST anomaly can even last until the following summer (mid-July) (Fig. 9a), and the NIO warming peaks in late-spring and lasts until summer (Fig. 9b). For the early transition, the NIO warming occurs from the summer in the developing year and lasts until the post-El Niño summer, with the peak phase in February. The cold WNP SST anomaly, however, is weak and only lasts until spring. This result means the AAC-SST feedback is weak for these early transitions, which can also be represented by small differences between these two indices over the WNP and NIO.

Figure 9c shows the equatorial easterly index representing the transition timing of El Niño to La Niña. The equatorial easterly index peaks in autumn and winter for both early- and late-transition El Niños. From the spring after the late-transition El Niño, no significant easterly anomalies can be found. For the early-transition El Niño, another peak of the equatorial easterly index appears from spring and lasts until summer. Thus, the equatorial easterly anomaly due to equatorial Pacific cooling after the early-transition El Niño pulls the AAC equatorward.

In summary, the AAC-SST feedback is stronger for latetransition El Niños than for early-transition El Niños. For the early transition, the AAC is mainly supported by the NIO part of the AAC-SST feedback since the previous winter, and the WNP part is weak and disappears in early-summer. For the late transition, the AAC is supported by the strong WNP part from winter to mid-summer and by the NIO part in summer. The easterly anomaly over the western equatorial Pacific, associated with the dipole precipitation anomaly over the Maritime Continent and western equatorial Pacific, is another important feedback to support the AAC and pull it equatorward in summer after the early-transition El Niño.

\subsection{Significance test}

To verify the above results, we investigate the two feedbacks in each El Niño year. For more than three out of the four late-transition El Niños, the AAC is supported by the WNP 
Fig. 10 Statistics of the two indices for individual El Niño years. Shown are WNP part of SST index (blue bar), NIO part of SST index (red bar), and equatorial easterly wind index (green bar) in a $\mathrm{DJF}^{0}, \mathbf{b ~ M A M}^{1}$, c JJA ${ }^{1}$ for individual El Niño year. The dashed line separates the early- and late-transition El Niños. Superscripts 0 and 1 of the y-label denote developing and decaying years of the El Niño, respectively

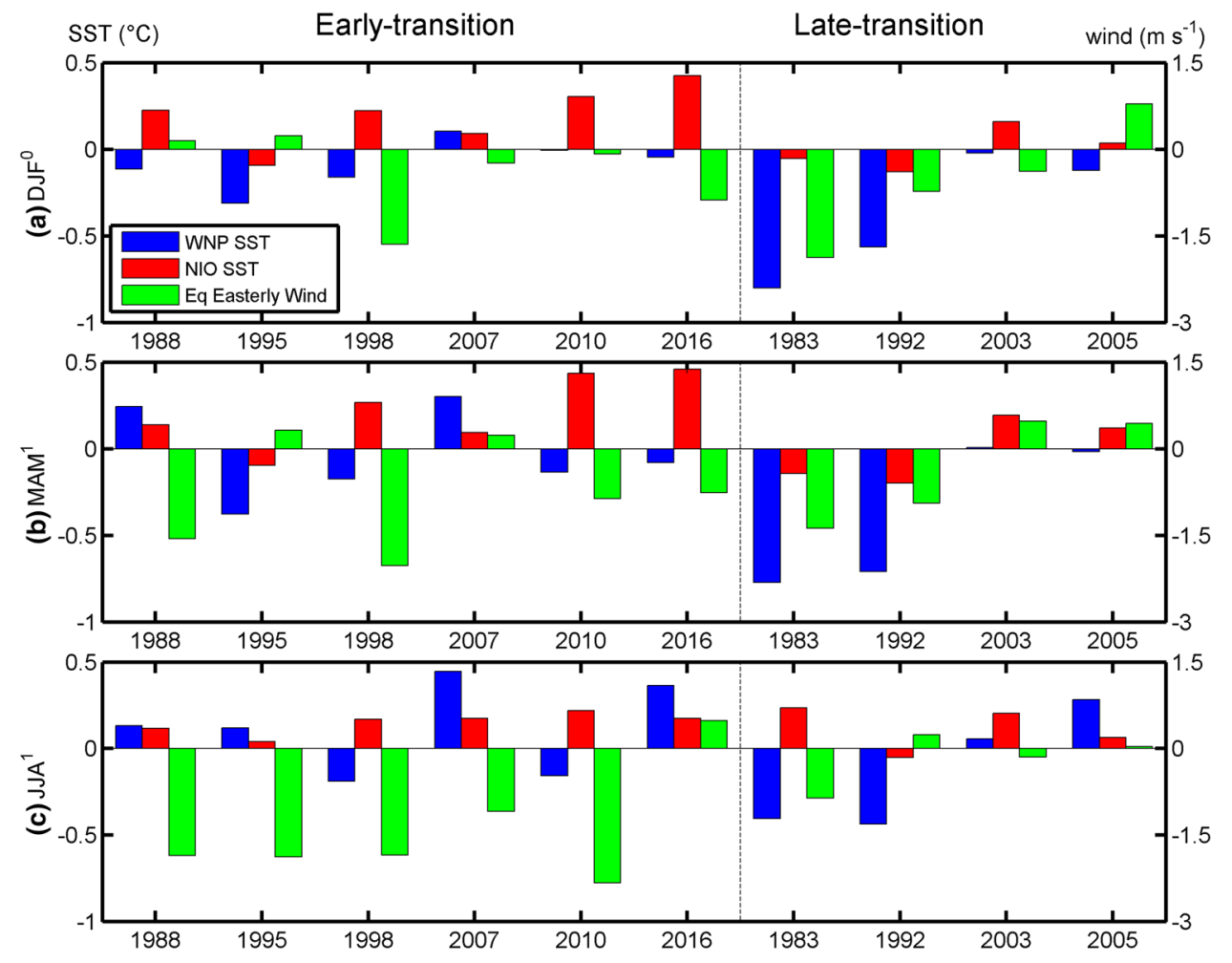

part of the AAC-SST feedback from the boreal winter to spring (Fig. 10a, b), and only half late-transition El Niños are accompanied by the WNP cooling in the ensuing summer (Fig. 10c). The NIO part begins to work in the ensuing summer for three out of the four late-transition El Niños (Fig. 10c).

The WNP cooling is weaker for early-transition El Niños than for late-transition El Niños. Five out of the six earlytransition El Niños are accompanied by the WNP SST cooling in the boreal winter (Fig. 10a). In the ensuing spring, the WNP cooling appears in four out of the six early-transition El Niños (Fig. 10b), while in only two out of the six El Niños the cold water appears in summer (Fig. 10c). The NIO acts to support the AAC from winter to summer in more than five out of the six early-transition El Niños. The strong western equatorial Pacific easterly anomaly appears in summer after five out of the six early-transition El Niños (Fig. 10c), pulling the AAC equatorward.

\section{Responses in long-term datasets and simulations}

\subsection{Responses in long-term datasets}

Since there are only six early-transition and four late-transition events during the period of 1979-2016, we want to test our findings using long-term observations and reanalysis products. We choose the long period of 1901-2016, and identify 15 early- and 10 late-transition El Niños (Fig. 11a, b). The long-term analysis results confirm the results obtained for the period of 1979-2016. In the summer after early-transition El Niños, positive precipitation anomaly is observed over the entire eastern part of China except for the lower reach of the Yangtze River, with the AAC center at $16^{\circ} \mathrm{N}$ and strong easterly wind anomaly over the equatorial Pacific (Fig. 11c). The slant rain band can be found from the Maritime Continent to the Indian subcontinent. The sandwich pattern of precipitation anomaly is also found in the summer after late-transition El Niños, with the AAC center near $22^{\circ} \mathrm{N}$ (Fig. 11d). Strong easterly wind anomaly over the NIO can be found for both types of El Niño, accompanied by underlying NIO warming.

Figure 12 shows the two indices representing the SSTAAC feedback and the equatorial easterly feedback. We can see similar results as those shown in Fig. 9. For these long-term records, the AAC-SST feedback is also stronger for the late transitions than for the early transitions, and the late transitions have stronger WNP cooling than the early transitions from the boreal winter to the following spring (Fig. 12a), although the WNP cooling cannot last to summer. The NIO warming works for both types of El Niño transition (Fig. 12b) and the easterly anomaly over the western equatorial Pacific also works to support the AAC and pull it equatorward in the summer after early-transition El Niños (Fig. 12c). In summary, our analysis using the long-term 
(a) Niño 3.4 indice

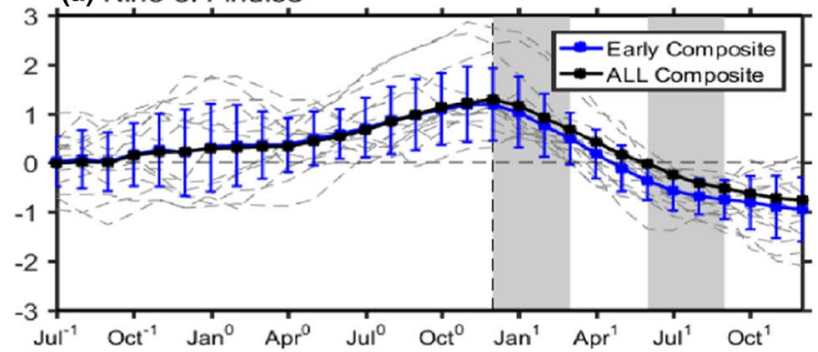

(c) Precipitation\&SST

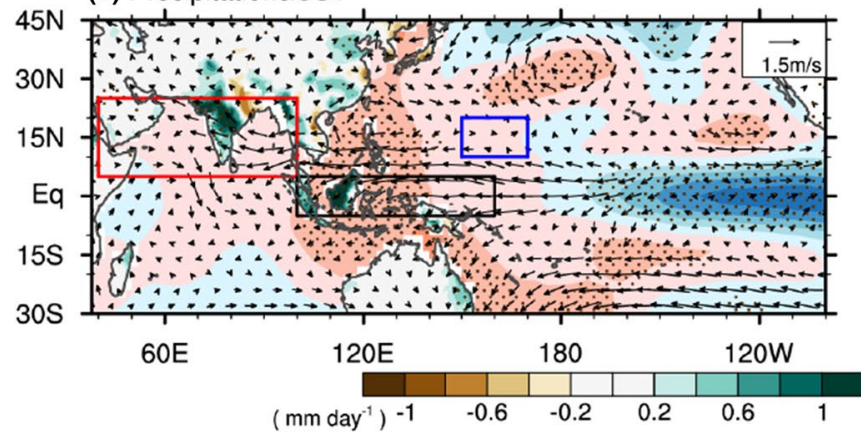

Fig. 11 Responses to early- and late-transition El Niños during 19012016. Shown are a seasonal evolutions of Niño3.4 index and $\mathbf{c}$ postEl Niño summer precipitation (shading over land) and SST (shading over ocean) anomalies, as well as $850-\mathrm{hPa}$ wind anomalies for 15 early-transition El Niños during the longer period of 1901-2016. Black and blue curves denote the composites of all (25) and 15 earlytransition El Niños, respectively. Grey curves denote individual early-

data confirms the different responses of EASM to the two types of El Niño transition.

\subsection{Different responses in CMIP5 model outputs}

We further investigate these different responses using CMIP5 model outputs. We select 38 CMIP5 models because each of them has a realistic phase locking of ENSO with the El Niño peak in the boreal winter (Fig. 13a, b). In the post-El Niño summer, negative Niño3.4 index is found after earlytransition El Niños (Fig. 13a), while positive Niño3.4 index is found after late-transition El Niños (Fig. 13b).

In the summer after early-transition El Niños (Fig. 13c), positive precipitation anomaly is simulated over the whole southeastern part of China, accompanied by the AAC with its center near $16^{\circ} \mathrm{N}$. The strong easterly wind anomaly, spanning the dipole pattern of positive precipitation anomaly (b) Niño 3.4 indice

Late-transition Years

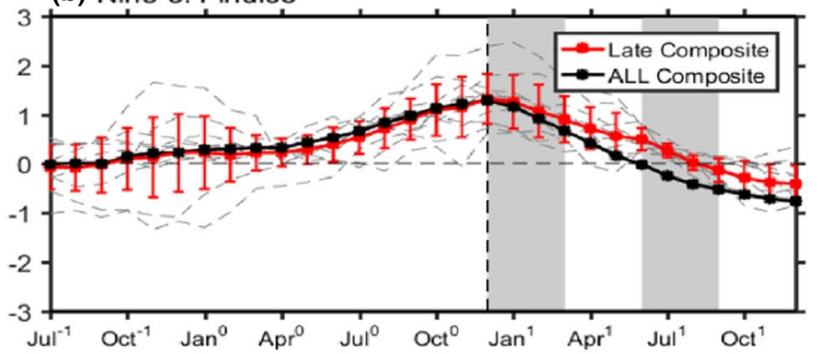

(d) Precipitation\&SST

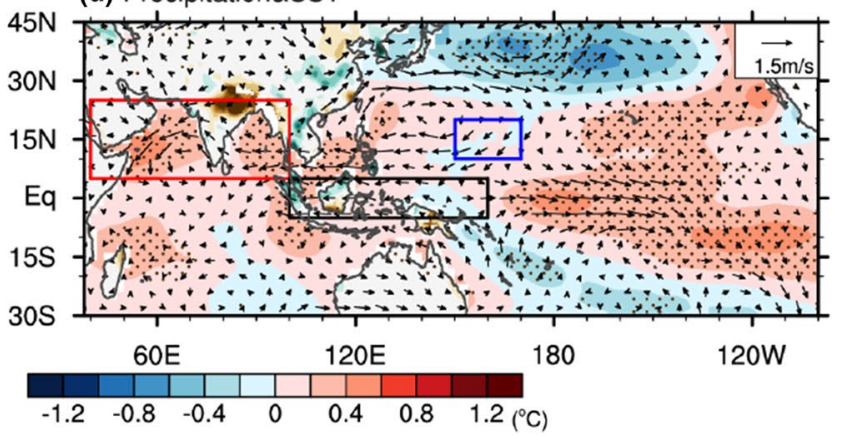

transition El Niño event in the models. b, d Are the same as a, c, except for 10 late-transition El Niños. Error bars indicate the standard deviation spread. Superscripts 0 and 1 of the $\mathrm{x}$-axis denote developing and decaying years of El Niño, respectively. Two grey shadings indicate the preceding winter $\left(\mathrm{DJF}^{0}\right)$ and following summer $\left(\mathrm{JJA}^{1}\right)$, respectively. Stippling indicates anomaly significant at the $10 \%$ significance level based on the $t$-test

over the Maritime Continent and negative anomaly over the western-to-central equatorial Pacific, is also simulated. The easterly wind anomaly, prevailing over the underlying NIO warming, is closely tied to the AAC, and the equatorial easterly anomaly is tied to the central-to-eastern Pacific cooling (Fig. 13e). The models reproduce well the responses observed after early-transition El Niños.

In the summer after late-transition El Niños (Fig. 13d), the rain band moves out of the Yangtze-Huaihe River valleys and appears from Japan to the North Pacific. Although the AAC is located further north than the AAC of early transitions, it moves out of the South China Sea and is located east of Philippines, leaving eastern China less affected. Accompanied by the NIO warming, the easterly wind anomaly only prevails in the Arabian Sea, and is separated from the WNP AAC (Fig. 13f). The models can simulate the northward migration of AAC after late-transition El Niños, while the 

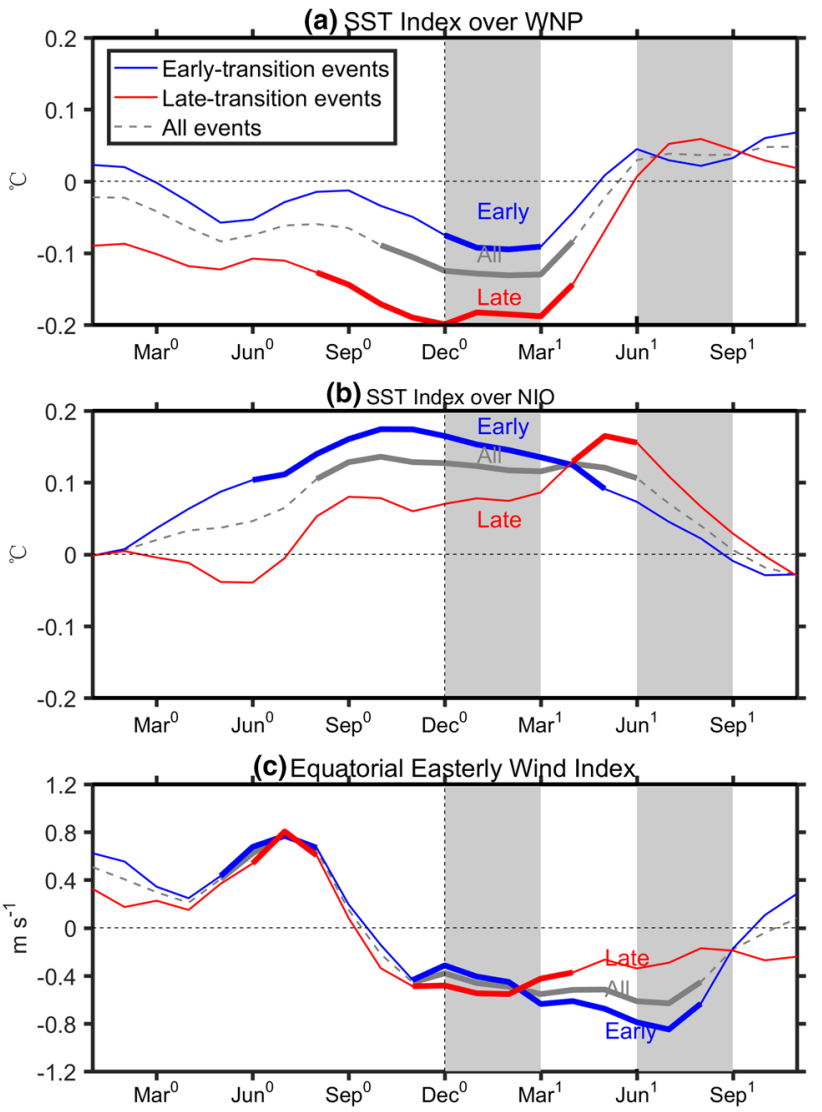

Fig. 12 Seasonal evolutions of two indices for different types of El Niño transition during 1901-2016. Same as Fig. 9, except for the longer period of 1901-2016

AAC in these models is located east of Philippines and is isolated from the NIO warming.

Figure 14 shows the two indices for these two types of El Niño transition. The WNP cooling works until spring for both types of El Niño transition (Fig. 14a), while the NIO warming continues to support the AAC in summer (Fig. 14b). The stronger WNP cooling for late transitions than early transitions, which is seen in the observations (Fig. 9), cannot be simulated by the CMIP5 models. After early-transition El Niños, the strong easterly wind anomaly over the western equatorial Pacific can be simulated, and it pulls the AAC equatorward (Fig. 14c).
In summary, the CMIP5 models can reproduce the observed responses after these two types of El Niño transition, except they underestimate the AAC-SST feedback for late transitions and the AAC in the models is only initiated by spring WNP cooling and loses connection to the NIO warming. Same results are also obtained for the earlytransition and late-transition models (not shown), when we divided these 38 CMIP5 models into 26 early- and 12 latetransition types based on the composite Niño3.4 index of each model (Table 1).

\section{Discussion and conclusions}

In this study, we divide El Niños into early- and late-transition types, and investigate responses of the EASM to these two types. Composite results indicate that there are wet signals in the entire southeastern China except for the lower reaches of the Yangtze River and coastal regions of eastern China in the summer after early-transition El Niños (Fig. 2b). In the summer after late-transition El Niños, however, positive rainfall anomaly is found in the Yellow-Huaihe River valleys and negative anomalies occur in northeastern and southern China, presenting a prominent tripolar structure (Fig. 2c). We find that the well-documented "sandwich structure" of post-El Niño summer rainfall mainly occurs after late-transition El Niños.

The location of the WNP AAC is found to be the key factor controlling these different responses of EASM rainfall. In the summer after late-transition El Niños, the AAC is centered at $\left(165^{\circ} \mathrm{E}, 25^{\circ} \mathrm{N}\right)$, and southeastern China is controlled by high-pressure anomaly and suppressed precipitation (Fig. 4b). After early-transition El Niños, however, the AAC is pulled equatorward by strong easterly anomaly in the western equatorial Pacific; thus, the strong high-pressure system moves out of southeastern China, losing control on the rainfall reduction there (Fig. 4a).

Figure 15 summarizes these different responses and two underlying mechanisms contributing to the WNP AAC after the two types of El Niño transition. For early-transition El Niños, the AAC-SST feedback is weak: the weak WNP cooling only works until spring and the NIO warming takes over from the winter to the following summer. In summer, the 
(a) Niño 3.4 indice

Early-transition Years

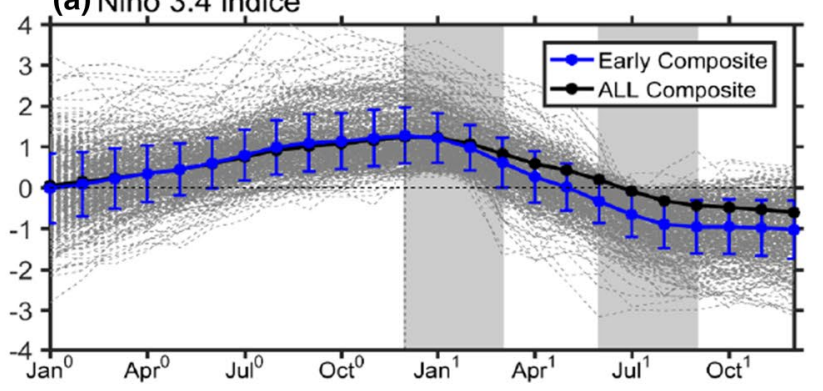

(c) Precipitation $\left(\mathrm{JJA}^{1}\right)$

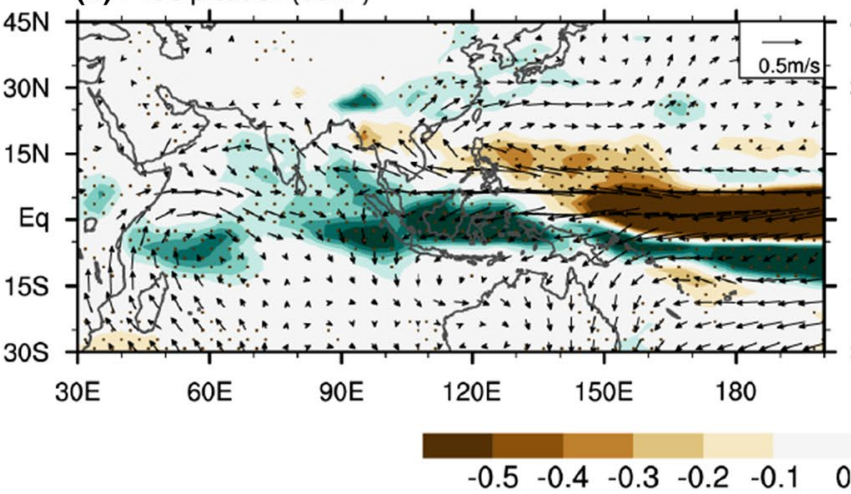

(e) $\operatorname{SST}\left(J J A^{1}\right)$

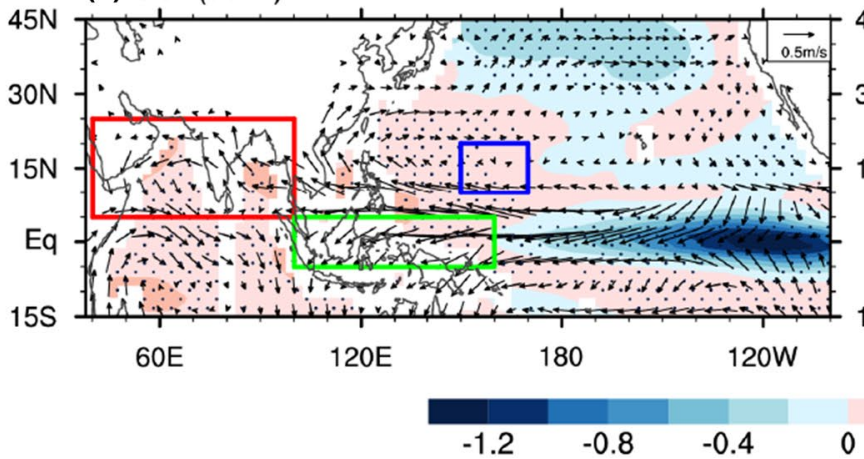

(b) Niño 3.4 indice

Late-transition Years

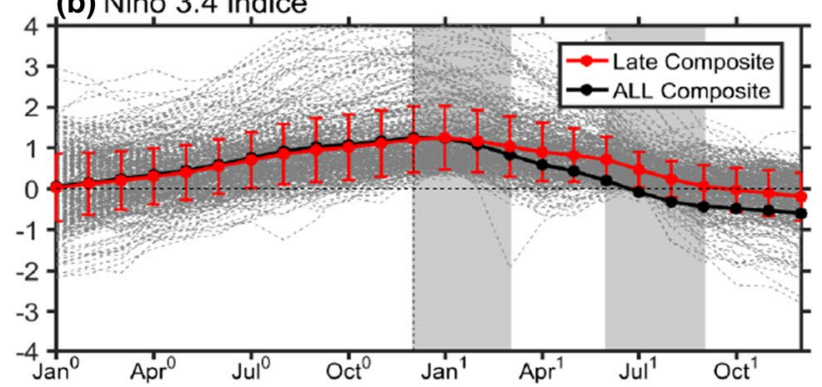

(d) Precipitation(JJA')

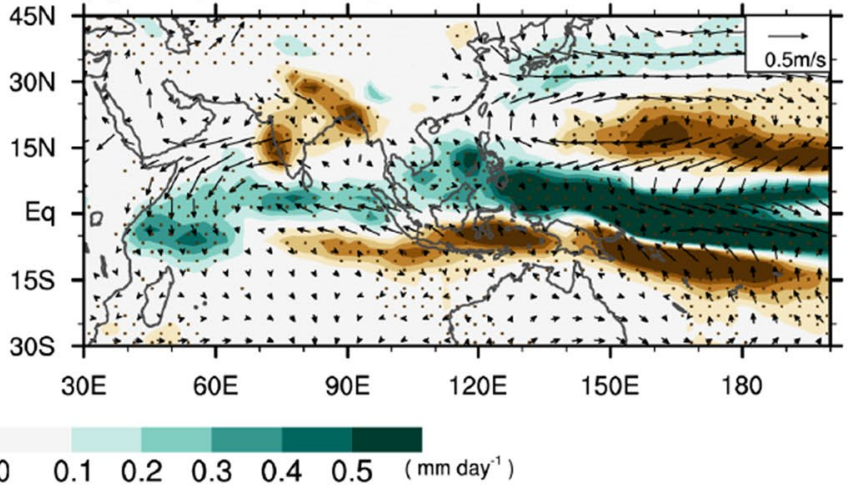

(f) SST(JJA $\left.{ }^{1}\right)$

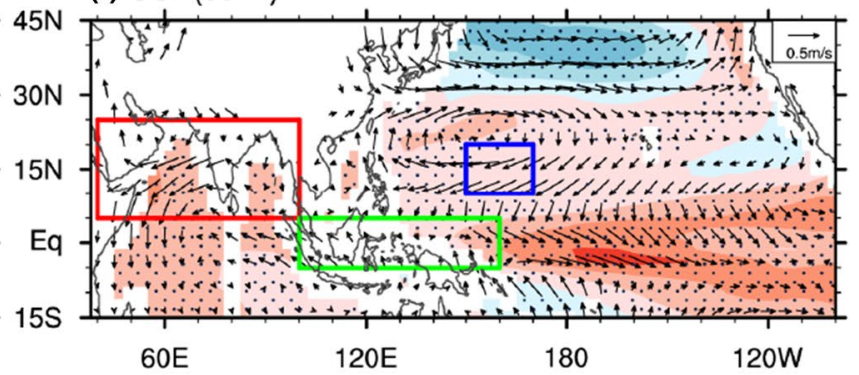

$\begin{array}{llll}0 & 0.4 & 0.8 & 1.2\left({ }^{\circ} \mathrm{C}\right)\end{array}$
Fig. 13 Responses to early- and late-transition El Niños in selected 38 CMIP5 models during 1901-2004. Shown are a seasonal evolutions of Niño3.4 index and post-El Niño summer $\mathbf{c}$ precipitation and e SST anomalies, as well as $850-\mathrm{hPa}$ wind anomalies for 437 earlytransition El Niños. Black and blue curves denote the composites of all (833) and 437 early-transition El Niños, respectively. Grey curves denote individual early-transition El Niño in these models. b, d, f Are the same as a, c, e, except for 396 late-transition El Niños. Error bars indicate the standard deviation spread. Superscripts 0 and 1 of the $\mathrm{x}$-axis denote developing and decaying years of El Niño, respectively. Two grey shadings indicate the preceding winter $\left(\mathrm{DJF}^{0}\right)$ and following summer $\left(\mathrm{JJA}^{1}\right)$, respectively. Stippling indicates anomaly significant at the $10 \%$ significance level based on the $t$-test 

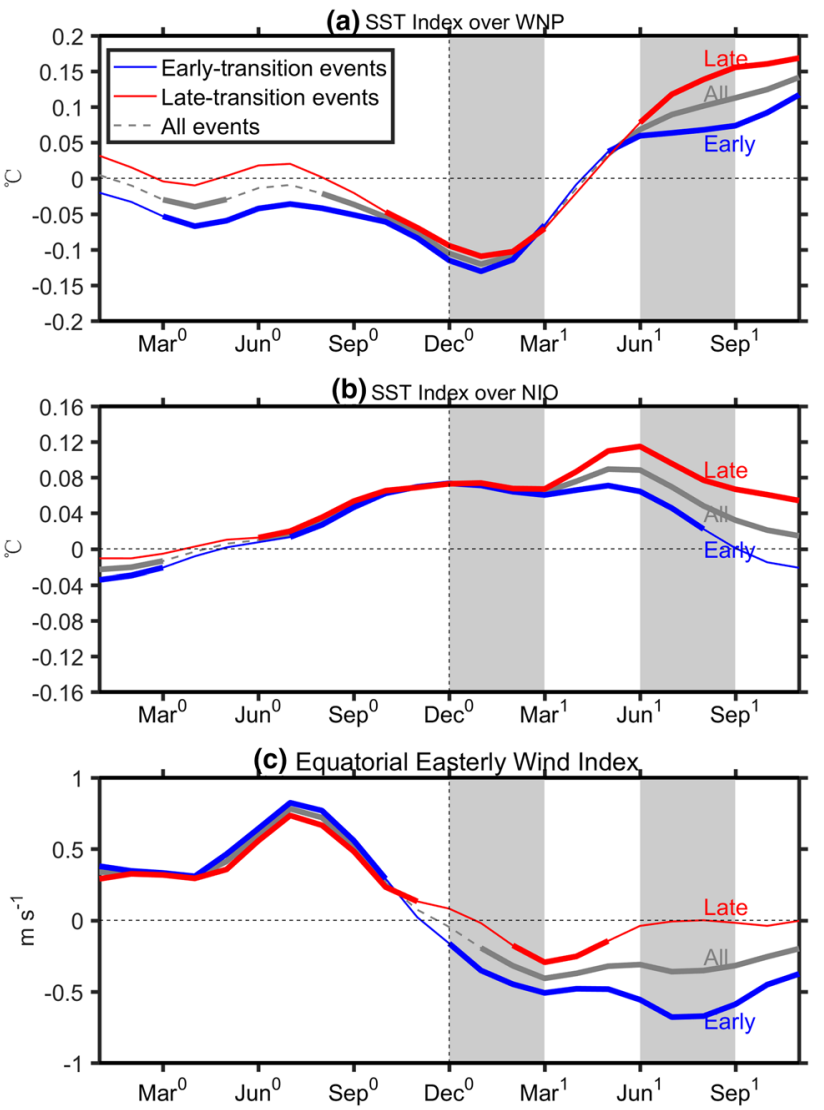

Fig. 14 Seasonal evolutions of two indices for different types of El Niño transition in CMIP5 models. Same as Fig. 9, except for 437 early- and 396 late-transition El Niños in these models easterly anomaly in the western equatorial Pacific, tied to the cold SST anomaly in the central-to-eastern Pacific and dipole precipitation pattern from the western equatorial Pacific to the Maritime Continent, can pull the WNP AAC equatorward (Fig. 15a). For late-transition El Niños, the WNP cooling works from winter to mid-summer to support the WNP AAC. From then on, the NIO warming continues to support the AAC, forming a strong AAC-SST feedback in summer. Without the effect of the easterly anomaly in the western equatorial Pacific, the WNP AAC tends to locate farther north than that after early-transition El Niños (Fig. 15b).

The analysis results using long-term data confirm these distinct responses to the two types of El Niño transition (Figs. 11, 12). The CMIP5 models can reproduce the observed responses after early-transition El Niños, while they underestimate the AAC-SST feedback after latetransition El Niños, and the AAC moves eastward to the east of Philippines and is separated from the NIO warming (Figs. 13, 14).

Our findings reported here should improve our understanding of EASM variability. Until now, it remains unresolved why the El Niño decaying length generates different AAC-SST feedbacks. Many factors, such as the Indian Ocean Dipole (Kug et al. 2006), El Niño strength (Wang et al. 2017), El Niño type (Feng et al. 2011; Huang et al. 2009; Yuan and Yang 2012), and decadal variation (Feng et al. 2014; Ohba 2013), may affect the AAC-SST feedback. The rainfall-related AAC-SST feedback, however, also affects the El Niño transition in turn. Study of this two-way interaction is beyond the scope of this paper, and needs to be studied in future.
Fig. 15 Schematic diagram. Shown are the responses of WNP AAC (JJA $\left.{ }^{1}\right)$ to a earlytransition and $\mathbf{b}$ late-transition El Niños. The dark/light red (blue) patches denote strong/ weak positive (negative) SST anomalies. The black vectors indicate anomalous surface wind anomalies. The AAC is indicated by black ellipse with arrowhead. The green (brown) clouds denote positive (negative) precipitation anomalies in post-El Niño summer. The numerator of the fraction $(\mathrm{x} / \mathrm{y})$ denotes the number of El Niño events that have the anomaly shown in corresponding seasons; and denominator, the number of all early or latetransition events. Superscripts 0 and 1 denote developing and decaying years of the El Niño, respectively

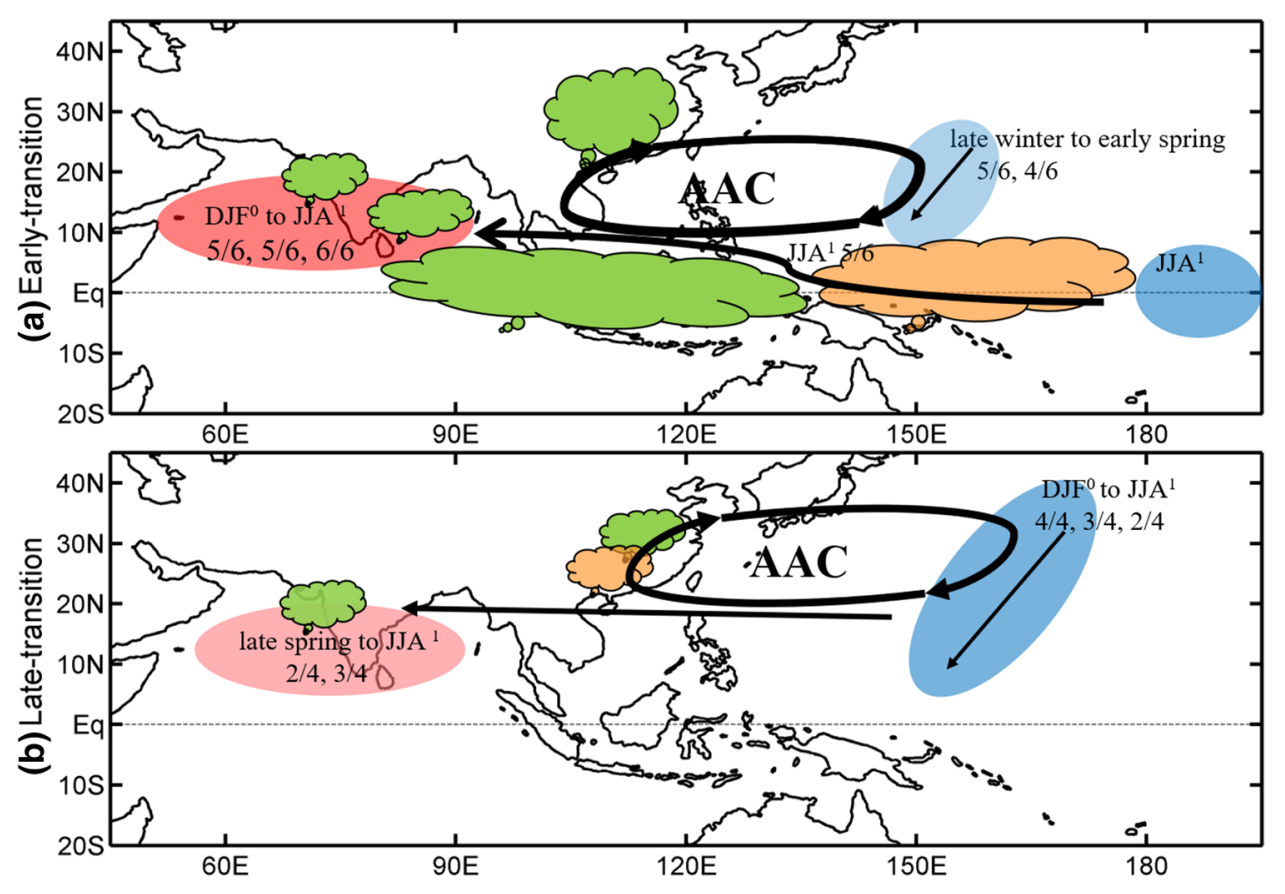


Acknowledgements This work was supported by the China National 973 Project (2015CB453200), the National Natural Science Foundation of China (41420104002), the IPOVAR Project (GASI-IPOVAI-02), and the Natural Science Foundation of Jiangsu province (BK20150907). BW acknowledges the supports from the US NSF (award \#AGS1540783), US NOAA/DYNAMO (\#NA13OAR4310167), and the National Research Foundation (NRF) of Korea through a Global Research Laboratory (GRL) Grant (MEST, \#2011-0021927). This paper is ESMC Contribution no. 250.

Open Access This article is distributed under the terms of the Creative Commons Attribution 4.0 International License (http://creativeco mmons.org/licenses/by/4.0/), which permits unrestricted use, distribution, and reproduction in any medium, provided you give appropriate credit to the original author(s) and the source, provide a link to the Creative Commons license, and indicate if changes were made.

\section{References}

Adler RF (2003) The version-2 global precipitation climatology project (GPCP) monthly precipitation analysis (1979-present). J Hydrometeor 4:1147

Boo K-O, Lim G-H, Kim K-Y (2004) On the low-level circulation over the western north Pacific in relation with the duration of El Niño. Geophys Res Lett 31:L10202. https://doi.org/10.1029/2004g10194 18

Chang CP, Zhang Y, Li T (2000) Interannual and interdecadal variations of the East Asian Summer monsoon and tropical Pacific SSTs. Part I: roles of the subtropical ridge. J Clim 13:4310-4325

Chen W, Park J-K, Dong B, Lu R, Jung W-S (2012) The relationship between El Niño and the western North Pacific summer climate in a coupled GCM: role of the transition of El Niño decaying phases. J Geophys Res Atmos 117:D12111. https://doi.org/10.1029/2011j d017385

Compo GP et al (2011) The twentieth century reanalysis project. Q J R Meteorol Soc 137:1-28. https://doi.org/10.1002/qj.776

Ding Y, Chan JC (2005) The East Asian summer monsoon: an overview. Meteorol Atmos Phys 89:117-142

Du Y, Xie SP, Gang H, Hu KM (2009) Role of air-sea interaction in the long persistence of El Niño-induced north Indian Ocean warming. J Clim 22:2023-2038

Feng J, Chen W, Tam CY, Zhou W (2011) Different impacts of El Niño and El Niño Modoki on China rainfall in the decaying phases. Int J Climatol 31:2091-2101

Feng J, Wang L, Chen W (2014) How does the East Asian summer monsoon behave in the decaying phase of El Niño during different PDO phases? J Clim 27:2682-2698

Gadgil S, Gadgil S (2006) The Indian Monsoon, GDP and agriculture. Econ Polit Wkly 41:4887-4895

Harris I, Jones PD, Osborn TJ, Lister DH (2014) Updated high-resolution grids of monthly climatic observations- the CRU TS3.10 dataset. Int J Climatol 34:623-642

Huang RH, Sun FY (1992) Impacts of the tropical western Pacific on the East Asian summer monsoon. J Meteorol Soc Jpn 70:243-256

Huang P, Huang RH, Huang P, Huang RH (2009) Relationship between the modes of winter tropical Pacific SST anomalies and the intraseasonal variations of the following summer rainfall anomalies in China. Atmos Ocean Sci Lett 2:295-300

Huang B et al (2016) Further exploring and quantifying uncertainties for extended reconstructed sea surface temperature (ERSST) version 4 (v4). J Clim 29:151211135749001

Kalnay E et al (1996) The NCEP/NCAR 40-year reanalysis project. Bull Am Meteorol Soc 77:437-472
Kosaka Y, Xie SP, Lau NC, Vecchi GA (2013) Origin of seasonal predictability for summer climate over the Northwestern Pacific. Proc Natl Acad Sci 110:7574-7579. https://doi.org/10.1073/ pnas. 1215582110

Kubota H, Kosaka Y, Xie SP (2016) A 117-year long index of the Pacific-Japan pattern with application to interdecadal variability. Int J Climatol 36:1575-1589

Kug JS, Li T, An SI, Kang IS, Luo JJ, Masson S, Yamagata T (2006) Role of the ENSO-Indian Ocean coupling on ENSO variability in a coupled GCM. Geophys Res Lett 33:370-386

Lee S-K, DiNezio PN, Chung E-S, Yeh S-W, Wittenberg AT, Wang C (2014) Spring persistence, transition, and resurgence of El Niño. Geophys Res Lett 41:8578-8585. https://doi.org/10.1002/2014g 1062484

Li Q (2014) The evolution of East Asian summer monsoon and drought 1 flood distribution on Eastern China during the Last 539 year. Adv Mater Res 955-959:3093-3097

Lin H (2008) Global extratropical response to diabatic heating variability of the Asian Summer Monsoon. J Atmos Sci 66:2697-2713

Liu F, Wang B (2013) Mechanisms of global teleconnections associated with the Asian Summer Monsoon: an intermediate model analysis. J Clim 26:1791-1806

Mcgregor S, Ramesh N, Spence P, England MH, Mcphaden MJ, Santoso A (2013) Meridional movement of wind anomalies during ENSO events and their role in event termination. Geophys Res Lett 40:749-754

Nitta T (1986) Long-term variations of cloud amount in the western Pacific region. J Meteorol Soc Jpn 64:373-390

Ohba M (2013) Important factors for long-term change in ENSO transitivity. Int J Climatol 33:1495-1509. https://doi.org/10.1002/ joc. 3529

Ohba M, Ueda H (2005) Basin-wide warming in the equatorial Indian Ocean associated with El Niño. SOLA 1:4 https://doi.org/10.2151/ sola.2006?045

Ohba M, Ueda H (2006) A Role of zonal gradient of SST between the Indian Ocean and the Western Pacific in localized convection around the Philippines. SOLA 2:4. https://doi.org/10.2151/ sola.2006-045

Ohba M, Ueda H (2007) An impact of SST anomalies in the Indian Ocean in acceleration of El Niño to La Niña transition. J Meteorol Soc Jpn 85:14

Ohba M, Ueda H (2009) Seasonally different response of the indian ocean to the remote forcing of El Niño: linking the dynamics and thermodynamics. SOLA 45:4 https://doi.org/10.2151/ sola.2009?045

Ohba M, Watanabe M (2012) Role of the Indo-Pacific interbasin coupling in predicting asymmetric ENSO transition and duration. J Clim 25:3321-3335. https://doi.org/10.1175/jcli-d-11-00409.1

Stuecker MF, Timmermann A, Jin FF, Mcgregor S, Ren HL (2013) A combination mode of the annual cycle and the El Niño/Southern oscillation. Nat Geosci 6:540-544

Stuecker MF, Jin FF, Timmermann A, Mcgregor S (2015) Combination mode dynamics of the anomalous Northwest Pacific anticyclone. J Clim 28:1093-1111

Sui C-H, Chung P-H, Li T (2007) Interannual and interdecadal variability of the summertime western North Pacific subtropical high. Geophys Res Lett 34:6. https://doi.org/10.1029/2006GL029204

Taylor KE, Ronald JS, Meehl GA (2012) An overview of CMIP5 and the experiment design. Bull Am Meteorol Soc 93:14. https://doi. org/10.1175/BAMS-D-11-00094.1

Wang B, Wu R, Fu X (2000) Pacific-East Asian teleconnection: how does ENSO affect East Asian climate? J Clim 13:1517-1536

Wang B, Wu R, Li T (2003) Atmosphere-warm ocean interaction and its impacts on Asian-Australian Monsoon variation. J Clim 16:1195-1211 
Wang B, Kang I-S, Lee J-Y (2004) Ensemble simulations of Asian Australian monsoon variability by 11 AGCMs. J Clim 17:803-818

Wang B, Ding Q, Fu X, Kang I-S, Jin K, Shukla J, Doblas-Reyes F (2005) Fundamental challenge in simulation and prediction of summer monsoon rainfall. Geophys Res Lett 32:291-310

Wang B, Xiang B, Lee J-Y (2013) Subtropical high predictability establishes a promising way for monsoon and tropical storm predictions. Proc Natl Acad Sci 110:5

Wang B, Li J, He Q (2017) Variable and robust East Asian Monsoon rainfall response to El Niño over the Past 60 years(1957-2016). Adv Atmos Sci 34:1235-1248

Wu R, Song L (2017) Spatiotemporal change of intraseasonal oscillation intensity over the tropical Indo-Pacific Ocean associated with El Niño and La Niña events. Clim Dyn:1-22

Wu B, Zhou TJ, Li T (2009) Seasonally evolving dominant interannual variability modes of East Asian climate. J Clim 22:2992-3005

Xiang B, Wang B, Yu W, Xu S (2013) How can anomalous western North Pacific subtropical high intensify in late summer? Geophys Res Lett 40:2349-2354

Xie P, Arkin PA (1997) Global precipitation: a 17-year monthly analysis based on gauge observations, satellite estimates, and numerical model outputs. Bull Am Meteorol Soc 78:2539-2558

Xie SP, Hafner J, Tokinaga H, Du Y, Sampe T, Hu KM, Huang G (2009) Indian ocean capacitor effect on Indo-Western Pacific climate during the summer following El Niño. J Clim 22:730-747

Xie SP, Yu K, Du Y, Hu K, Chowdary JS, Huang G (2016) Indowestern Pacific ocean capacitor and coherent climate anomalies in post-ENSO summer: a review. Adv Atmos Sci 33:411-432
Xue F, Liu CZ (2008) The influence of moderate ENSO on summer rainfall in eastern China and its comparison with strong ENSO. Chin Sci Bull 53:791-800

Yuan Y, Yang S (2012) Impacts of different types of El Niño on the East Asian climate: focus on ENSO cycles. J Clim 25:7702-7722. https://doi.org/10.1175/jcli-d-11-00576.1

Yun K-S, Ha K-J, Yeh S-W, Wang B, Xiang B (2014) Critical role of boreal summer North Pacific subtropical highs in ENSO transition. Clim Dyn 44:1979-1992. https://doi.org/10.1007/s0038 2-014-2193-6

Zhang R (1999) A diagnostic study of the impact of El Niño on the precipitation in China. Adv Atmos Sci 16:229-241

Zhang R, Sumi A (2002) Moisture circulation over East Asia during El Niño episode in Northern Winter, Spring and Autumn. J Meteorol Soc Jpn 80:213-227

Zhang R, Sumi A, Kimoto M (2009) Impact of El Niño on the East Asian monsoon. J Meteorol Soc Jpn 74:49-62

Zhou W, Chan CL, Li C (2005) South China Sea summer monsoon onset in relation to the off-equatorial ITCZ. Adv Atmos Sci 22:665-676

Publisher's Note Springer Nature remains neutral with regard to jurisdictional claims in published maps and institutional affiliations. 